\title{
Entry, Descent, and Landing With Propulsive Deceleration: Supersonic Retropropulsion Wind Tunnel Testing
}

Bryan Palaszewski

Glenn Research Center, Cleveland, Ohio 


\section{NASA STI Program . . . in Profile}

Since its founding, NASA has been dedicated to the advancement of aeronautics and space science. The NASA Scientific and Technical Information (STI) program plays a key part in helping NASA maintain this important role.

The NASA STI Program operates under the auspices of the Agency Chief Information Officer. It collects, organizes, provides for archiving, and disseminates NASA's STI. The NASA STI program provides access to the NASA Aeronautics and Space Database and its public interface, the NASA Technical Reports Server, thus providing one of the largest collections of aeronautical and space science STI in the world. Results are published in both non-NASA channels and by NASA in the NASA STI Report Series, which includes the following report types:

- TECHNICAL PUBLICATION. Reports of completed research or a major significant phase of research that present the results of NASA programs and include extensive data or theoretical analysis. Includes compilations of significant scientific and technical data and information deemed to be of continuing reference value. NASA counterpart of peer-reviewed formal professional papers but has less stringent limitations on manuscript length and extent of graphic presentations.

- TECHNICAL MEMORANDUM. Scientific and technical findings that are preliminary or of specialized interest, e.g., quick release reports, working papers, and bibliographies that contain minimal annotation. Does not contain extensive analysis.

- CONTRACTOR REPORT. Scientific and technical findings by NASA-sponsored contractors and grantees.
- CONFERENCE PUBLICATION. Collected papers from scientific and technical conferences, symposia, seminars, or other meetings sponsored or cosponsored by NASA.

- SPECIAL PUBLICATION. Scientific, technical, or historical information from NASA programs, projects, and missions, often concerned with subjects having substantial public interest.

- TECHNICAL TRANSLATION. Englishlanguage translations of foreign scientific and technical material pertinent to NASA's mission.

Specialized services also include creating custom thesauri, building customized databases, organizing and publishing research results.

For more information about the NASA STI program, see the following:

- Access the NASA STI program home page at http://www.sti.nasa.gov

- E-mail your question to help@sti.nasa.gov

- Fax your question to the NASA STI Information Desk at 443-757-5803

- Phone the NASA STI Information Desk at 443-757-5802

- Write to: STI Information Desk NASA Center for AeroSpace Information 7115 Standard Drive Hanover, MD 21076-1320 
NASA/TM-2012-217746

\section{Entry, Descent, and Landing With Propulsive Deceleration: Supersonic Retropropulsion Wind Tunnel Testing}

Bryan Palaszewski

Glenn Research Center, Cleveland, Ohio

Prepared for the

50th Aerospace Sciences Meeting

sponsored by the American Institute of Aeronautics and Astronautics

Nashville, Tennessee, January 9-12, 2012

National Aeronautics and

Space Administration

Glenn Research Center

Cleveland, Ohio 44135 
This work was sponsored by the Fundamental Aeronautics Program at the NASA Glenn Research Center.

Level of Review: This material has been technically reviewed by technical management.

Available from

NASA Center for Aerospace Information

7115 Standard Drive

Hanover, MD 21076-1320
National Technical Information Service 5301 Shawnee Road Alexandria, VA 22312

Available electronically at http://www.sti.nasa.gov 


\title{
Entry, Descent, and Landing With Propulsive Deceleration: Supersonic Retropropulsion Wind Tunnel Testing
}

\author{
Bryan Palaszewski \\ National Aeronautics and Space Administration \\ Glenn Research Center \\ Cleveland, Ohio 44135
}

The future exploration of the Solar System will require innovations in transportation and the use of entry, descent, and landing (EDL) systems at many planetary landing sites. The cost of space missions has always been prohibitive, and using the natural planetary and planet's moons' atmosphere for entry, descent, and landing can reduce the cost, mass, and complexity of these missions. This paper will describe some of the EDL ideas for planetary entry and survey the overall technologies for EDL that may be attractive for future Solar System missions. Future EDL systems may include an inflatable decelerator for the initial atmospheric entry and an additional supersonic retro-propulsion (SRP) rocket system for the final soft landing. As part of those efforts, NASA began to conduct experiments to gather the experimental data to make informed decisions on the "best" EDL options.

A model of a three engine retro-propulsion configuration with a $2.5 \mathrm{in}$. diameter sphere-cone aeroshell model was tested in the NASA Glenn 1- by 1-Foot Supersonic Wind Tunnel (SWT). The testing was conducted to identify potential blockage issues in the tunnel, and visualize the rocket flow and shock interactions during supersonic and hypersonic entry conditions. Earlier experimental testing of a $70^{\circ}$ Viking-like (sphere-cone) aeroshell was conducted as a baseline for testing of a supersonic retropropulsion system. This baseline testing defined the flow field around the aeroshell and from this comparative baseline data, retro-propulsion options will be assessed. Images and analyses from the SWT testing with 300- and 500-psia rocket engine chamber pressures are presented here. The rocket engine flow was simulated with a non-combusting flow of air.

\section{Introduction}

Entry, descent, and landing are a series of events needed to safely land on the surface of another atmosphere-bearing body in the solar system. Mars, Venus, the outer planets, and the outer planet moon, Titan, all require technologies that will protect the spacecraft from the high temperatures created during the initial hypersonic entry, and finally slow the vehicle from that hypersonic speed into the supersonic regime, then to subsonic velocities and to the final touchdown. In the outer planet atmospheres, the final landing would be replaced with a buoyancy system such as an airship, balloon, or an aircraft.

\section{Historical Missions}

Landing space vehicles on other planetary bodies is a challenge in propulsion, precision control, and guidance. As there is no appreciable atmosphere surrounding Earth's Moon, the lunar landings of the robotic Surveyor and human Apollo missions used propulsion for the entire descent. The same was true for the successful Luna and Lunakhod flights of the U.S.S.R. For Venus with its dense atmosphere, landing vehicles used aeroshell and parachute combinations, with crushable elements (balsa wood, etc.) to absorb the final landing energy. On Mars, the landing vehicles became more massive and complex (Viking, Pathfinder, Mars Exploration Rovers (MER), Mars Science Laboratory (MSL)), and the since the atmosphere was very thin, the final landing systems was a combination for aeroshell, parachute and retro rockets. To allow landing in the more rugged areas of Mars, an additional airbag system was devised for the Pathfinder and MER landers to assure a successful landing at rock strewn sites. 


\section{Mars}

Several EDL configurations are under assessment for Mars. Figure 1 presents the historical comparison of the U.S. Mars entry capsules (Ref. 1). The typical $70^{\circ}$ cone angle for these configurations was selected for high stability and high drag. As the planet's atmosphere is quite thin, the blunt body can provide the needed drag for relatively small payloads of up to 1 metric ton. As the mass of the lander vehicle increases, a different set of EDL technologies are required. Based on past studies (Refs. 2 to 4), parachutes are impractical for vehicles with lander masses of over 20 metric tons. The parachutes are too big to deploy effectively and reliably. Therefore a combination of inflatable decelerators (for hypersonic and supersonic speeds) and supersonic retro-propulsion has been suggested. Many past studies have investigated landing on Mars with aerodynamic systems (Refs. 5 to 8). However, the most recent studies imply that the past studies assumptions were too optimistic and are in need of revision to assure success. Supersonic retro propulsion, perhaps beginning as early as Mach 5, will therefore likely be required for soft landing on Mars.

\section{Experimental Planning}

While the Viking-like aeroshell design has proven successful for missions, higher mass missions of many tens of tons will likely require more energetic retro-propulsion. Figures 2 and 3 show some of the historical testing on supersonic retro-propulsion (Ref. 3). This testing was only pursued with relatively small models and did not result in flight test hardware. To expand the relatively small data base of supersonic retro-propulsion information, a series of test programs were established and planned. The NASA Glenn Research Center's 1- by 1 Foot Supersonic Wind Tunnel (SWT) was used for the testing. It has a wide range of test velocities from Mach 2.0 to 6.0. Several types of data were gathered during the testing: surface pressure measurements, surface temperature measurements, and low speed and high speed digital Schlieren video movie imaging.

Models were developed for a 2.5-in. diameter aeroshell. The 2.5-in. diameter size was selected based on the previous wind tunnel testing of the aerodynamic blockage of the tunnel. The initial model was based on the $70^{\circ}$ sphere-cone shape of the Viking entry capsule. It was attached to a sting-strut that was adjustable and can hold the model at a flexible angle of attack (AoA) of $0^{\circ}$ to $20^{\circ}$. The model and sting strut were made of stainless steel. The model was also instrumented with both temperature sensors and pressure transducers. There were 3 thermocouples and 9 pressure ports on the windward side of aeroshell. There were also three thermocouples and three pressure ports on the leeward side of aeroshell. One additional thermocouple was placed near the trailing edge of the strut. High frequency pressure transducers (Kulites) were used to measure the engine chamber pressures and tunnel wall pressures in three locations. Optical access to the test section allowed imaging with low speed and high speed Schlieren video movie recording. The high speed Schlieren recordings were made at 500 frames per second.

\section{Test Data}

In each test run, the tunnel pressure increased until the flow was started on the model and a stable bow shock was established. The pressure was then adjusted until the minimum pressure for tunnel operation was reached. Data was taken at this point, and then successive data points were taken at the remaining Mach Numbers. Measurements were taken at Mach = 2.5, 3.0, 3.5, 4.0, and 5.0. Trailerprovided air was used for the simulated rocket engine flow. The rocket nozzle design was derived from Reference 4. Testing commenced on March 17, 2010 for a 1 day period.

During the testing, it was noted that with the 2.5-in. model, an initial stable bow shock could be established at all Mach Numbers. As expected from previous testing, no unanticipated aerodynamic blockage occurred when the engines were not firing. When the rocket engines were firing, tunnel unstarts occurred on several runs, and their occurrences are noted in Table I. The tunnel unstarts occurred with all 
of the 500 psia runs at $\mathrm{M}=2.5$ and 3.0 and with all of the 300 psia runs at $\mathrm{M}=2.5$. At all other conditions, excellent model performance was demonstrated with minimal wall interactions.

Figure 3 shows a typical Schlieren image for the baseline SWT testing 3 retro-propulsion engines. The Mach Number was 2.91 ( $\mathrm{M}=3.0$ range). The angle of attack was $0^{\circ}$. Note that at $\mathrm{M}=3.0$, the bow shock has a small interaction with the tunnel walls in the image. Data was gathered in the $1 \times 1 \mathrm{SWT}$ at Mach Number $=3.5,4.0$, and 5.0, with the angle of attack at $0.0^{\circ}$, and these results are shown in Figures 4, 5, 6, and 7, respectively. As the Mach number increases, there is less noticeable or no wall shock interaction in the images. On most runs, we were attempting to reach the lowest Reynolds Number/foot and the lowest total pressure at each Mach Number, to more accurately simulate the Mars entry conditions. Higher values of Reynolds Number/foot can represent other atmospheric entries: for Earth, the outer planets, or Titan.

The location of the bow shock very close to the sphere-cone model was unforeseen. The rocket engines in past testing have used higher engine pressures of up to 1500 psia, and thus the bow shock is often far from the body, perhaps one to several entry vehicle diameters away. The lower pressures used here were seen to penetrate the bow shock and that shock remained very near the entry body model. Such shock locations will have likely significant influence on vehicle heating due to shock impingement, etc.

An important parameter for the retro-propulsion testing is the thrust coefficient. It is the ratio of the thrust of the vehicle to the drag of the vehicle and is computed with this equation (Ref. 3):

$$
\mathrm{C}_{\mathrm{T}}=\frac{2}{\gamma_{\infty} \mathrm{M}_{\infty}{ }^{2}} \frac{\mathrm{P}_{\mathrm{e}}}{\mathrm{P}_{\infty}} \frac{\mathrm{A}_{\mathrm{e}}}{\mathrm{A}_{\mathrm{B}}}\left(1+\gamma_{\mathrm{e}} \mathrm{M}_{\mathrm{e}}{ }^{2}\right)
$$

where

$\mathrm{C}_{\mathrm{T}}$

Gamma, infinity

$\mathrm{M}$, infinity

$\mathrm{P}_{\mathrm{e}}$

$P$, infinity

$\mathrm{A}_{e}$

$\mathrm{A}_{\mathrm{B}}$

Gamma, exit

$\mathrm{M}_{\mathrm{e}}$
Thrust coefficient

Ratio of specific heats at infinity

Mach Number at infinity

Pressure at nozzle exit

Pressure at infinity (tunnel pressure)

Nozzle exit area

Test article projected area

Ratio of specific heats at nozzle exit

Mach Number at nozzle exit

Figure 8 illustrates the thrust coefficient versus Mach Number for four engine chamber pressures: $200,300,500$, and 1500 psia. The engine expansion ratio is 10:1. For the test cases below 500 psia, the thrust coefficient is a maximum of 0.36 , Only when the chamber pressure is near 1500 psia and near $\mathrm{M}=2.0$ will the thrust coefficient be equal to or greater than 1.0. Computations of the thrust coefficients at other planned expansion ratios (4:1, 20:1, and 50:1) show very similar results.

The retro- propulsion model configurations were planned to easily change the nozzle expansion ratio and the model's angle of attack. The overall design of a retro-propulsion model is shown in Figures 9, 10, and 11. Three expansion rations of 10:1, 20:1, and 4:1 are shown, respectively. Appendices A1, A2, and A3 show the Schlieren images from the runs with a chamber pressure of 300 and 500 psia, at an angle of attack of $0.0^{\circ}, 10.0^{\circ}$, and $15.0^{\circ}$. Over the entire test program, rocket engine chamber pressures of 200 , 300 , and 500 psia were tested with the 10:1 rocket engine expansion ratio. Appendix B provides the test conditions for each run: tunnel total and static pressures and the tunnel Reynolds Number/foot. Appendix C provides a detailed drawing of the windward side of the aeroshell test model. 


\section{Thoughts on Alternate Aerodynamic and Fin Configurations}

Due to the severity and large variations of the flow field from the retro rockets, extensions from the entry body may be an important option for stability enhancements. Past testing at supersonic speed of fin extensions (grid fins, etc.) shows that such configurations can provide the stability enhancements for missiles and human rated vehicles (Soyuz, etc.). Figure 12 shows the configuration for the Soyuz launch escape system (Ref. 9). The 4 grid fins are mounted on the sides of the vehicles and provide enhanced stability during the use of the launch escape system. Additionally, wind tunnel testing for the Orion Crew Exploration Vehicle (CEV) was conducted (Ref. 9) with several configurations of fins and testing was conducted at up to Mach 2.5. United States (U.S.) Army and international missile testing (Refs. 10 to 21) also evaluated grid fins. The missile testing was for long slender missiles, and hence the application may be for a more restricted set of higher lift to drag (L/D) EDL configurations (biconic aeroshells, etc.). Other configurations using a petal brake (Ref. 22) may also be compatible with the lower lift to drag (L/D) SRP configurations.

\section{Concluding Remarks}

Experimental programs were planned and executed to gather data of supersonic propulsive deceleration (or supersonic retro-propulsion). Initial data gathering was successful and this data will be used as the comparative baseline for upcoming larger scale retro-propulsion testing. Schlieren imaging was captured to assess the successful formation of the bow shock surrounding the aeroshell. In some cases, the shock interactions with the SWT walls occurred and were also visualized. The high speed camera video at 500 frames per second identified the chaotic nature of the retro-rocket-shock interactions. More detailed data and image analyses are continuing. Test planning and model development has been conducted for additional retro-rocket equipped aeroshells with different area ratio rocket nozzles: 4:1, 20:1, and 50:1. Due to test time limitations, the 4:1, 20:1, and 50:1 expansion ratios were not tested.

Entry, descent, and landing technologies are under development for the high mass Mars Entry system (HMMES). Many investigations of aerodynamic deceleration for the outer planets have been conducted as well. The challenges for EDL are numerous, especially for inflatable decelerator and the interactions that will occur with propulsive deceleration retro propulsion. The high velocities involved in entry and descent will require high temperature materials that are flexible for folding into a small volume, but reliable when they are deployed to their full diameter.

Many exciting possibilities are foreseen for Mars and outer planet exploration and exploitation (Refs. 23 to 39). The resources of the outer planets may allow fueling of nuclear fusion vehicles and other power plants that may be the engine for all of Earth's energy. Wresting fuels such as hydrogen and helium 3 from the gas giant planets may be a critical element of outer planet exploration and also flight to the nearby stars. The EDL systems will be an integral part of all of these exploration and exploitation scenarios.

\section{References}

1. Karl T. Edquist, Artem A. Dyakonov, Michael J. Wright, and Chun Y. Tang, “Aerothermodynamic Environments Definition for the Mars Science Laboratory Entry Capsule,” AIAA-2007-1206, 45th AIAA Aerospace Sciences Meeting and Exhibit, Reno, Nevada, 8-11, January 2007.

2. Karl T. Edquist and Stephen J. Alter, "Computational Aeroheating Predictions for Mars Lander Configurations,” AIAA-2003-3639, 36th AIAA Thermophysics Conference, Orlando, Florida, 23-26 June 2003.

3. Philip O. Jarvinen and Richard H. Adams, "The Aerodynamic Characteristics of Large Angled Cones with Retrorockets: Final Report,” Contract No. NAS 7-576, Prepared by MITHRAS, Report number MC 70 - 3001 - R2 (BNY), February 1970.

4. Putnam, L. and Capone, F., "Experimental Determination of Equivalent Solid Bodies to Represent Jets Exhausting into a Mach 2.20 External Stream,” NASA TN-D-5553, December 1969. 
5. Palaszewski, B., Frisbee, R., “Advanced Propulsion for the Mars Rover Sample Return Mission,” AIAA PAPER 88-2900, Jul 01, 1988.

6. Hepp, Aloysius F., Linne, Diane L., Landis, Geoffrey A. Inc., Groth, Mary F. Colvin, James E., "Production and Use of Metals and Oxygen for Lunar Propulsion," NASA-TM-105195, AIAA PAPER 91-3481, Jan 01, 1991.

7. Linne, Diane L., and Meyer, Michael L., “Technical prospects for utilizing extraterrestrial propellants for space exploration,” NASA-TM-105263 presented at the 42nd International Astronautical Congress, Montreal, Quebec, 5-11 Oct. 1991; sponsored by International Astronautical Federation International Astronautical Congress Montreal, Quebec, 5-11 Oct. 1991.

8. Rice, E., "Final Report On Advanced System Concept For Total ISRU Based Propulsion And Power Systems For Unmanned And Manned Mars Exploration,” Orbital Technologies Corporation, National Institute for Advanced Concepts (NIAC) Phase II Contract, Research Grant 07600-041, OTC-GS0096-FR-2002-1, Universities Space Research Association (USRA), 30 April 2002. Also, see: http://www.niac.usra.edu/files/studies/final_report/pdf/395Rice.pdf

9. Daniel A. Pruzan, et al. "Grid Fin Stabilization of the Orion Launch Abort Vehicle," 29th AIAA Applied Aerodynamics Conference 27-30 June 2011, Honolulu, Hawaii, AIAA 2011-3018.

10. M. Khalid, Y. Sun, and H. Xu., “Computation of Flows Past Grid Fin Missiles,” Institute for Aerospace Research, National Research Council, Ottawa, KIA OR6, Ontario, Canada, May 1998, and published in RTO MP-5. ftp://ftp.rta.nato.int/PubFullText/RTO/MP/RTO-MP-005/\$MP-005-12.pdf

11. DeSpirito, et al., "Viscous CFD Calculations of Grid Fin Missile Aerodynamics in the Supersonic Flow Regime,” ARL-RP-19, April 2001, AIAA 2001-0257.

12. James DeSpirito, Harris L. Edge, Paul Weinacht, Jubaraj Sahu, and Surya Dinavahi, "Computational Fluid Dynamic (CFD) Analysis of a Generic Missile With Grid Fins,” ARL-TR-2318, September 2000.

13. K. Mohamed Bak, "Experimental Investigation and Computational Fluid Dynamics Analysis of Missile With Grid Fin in Subsonic Flow,” International Journal of Engineering Science and Technology, Vol. 2(11), 2010, 6214-6220.

14. Philippe Reynier, Uwe Reisch, José-Maria Longo, Rolf Radespiel, “Flow predictions around a missile with lattice wings using the actuator disc concept,” Aerospace Science and Technology, Volume 8, Issue 5, July 2004, Pages 377-388.

15. DeSpirito, J., Vaughn, M., Washington, W.D. "CFD investigation of canard controlled missile with planar and grid fins in supersonic flow,” AIAA Paper 2002-4509, August 2002.

16. Gregg Abate, Gerald Winchenbach, and Wayne Hathaway, "Transonic Aerodynamic and Scaling Issues for Lattice Fin Projectiles tested in a Ballistics Range,” 19th International Symposium of Ballistics, 7-11 May 2001, Interlaken, Switzerland.

17. James DeSpirito, Harris L. Edge, Paul Weinacht and Juburaj Sahu. "CFD Analysis of Grid for Maneuvering Missiles,” AIAA-2000-0391.

18. E.Y. Fournier, "Wind tunnel investigation of a high L/D projectile with grid fin and conventional planar control surfaces”. $19^{\text {th }}$ International Symposium of Ballistics, 7-11 May 2001, Interlaken, Switzerland.

19. John E. Burkhalter, Roy J. Hartfield, and Todd M.Leleux "Nonlinear Aerodynamic Analysis of Grid Fin Configurations,” Journal of Aircraft Vol. 32 No. 3, May-June 1995.

20. Ross A. Brooks and John E. Burk halter "Experimental and Analytical Analysis of Grid Fin Configurations,” Journal of Aircraft Vol. 26 No. 9, September1989.

21. John E. Burkhalter and Harris M. Frank "Grid Fin Aerodynamics for Missile Applications in Subsonic Flow,” Journal of Spacecraft and Rockets. Vol. 33, No. 1 Jan - Feb 1996.

22. Andrews, Dana, "Design Optimization of High Mass Mars Entry Systems," Paper Number IAC08.D2.3.8 Andrews Space \& Technology, 2008.

23. Powell, Paniagua, Maise, Ludewig, Todosow Exploration of Jovian Atmosphere Using Nuclear Ramjet Flyer, IAF 98-S.6.08, PUR-4, 24 July '98. Also, see: http://www.newworlds.com/reports/PUR4.PDF 
24. John Paniagua, James R. Powell and George Maise, "Europa Sample Return Mission Utilizing High Specific Impulse Propulsion Refueled with Indigenous Resources,” Report No. PUR. 21, PHASE I. FINAL REPORT, Plus Ultra Technologies, Inc., National Institute for Advanced Concepts (NIAC) Phase I Grant 07600-077, Prime Contract Number NAS5-98051, November 30, 2001. Also see: http://www.niac.usra.edu/files/studies/final_report/pdf/638Paniagua.pdf

25. V.I. Shematovich and R.E. Johnson, "NEAR-SURFACE OXYGEN ATMOSPHERE AT EUROPA," Adv. Space Res. Vol. 27, No. 11, pp. 1881-1888, 2001, Pergamon Press, (C 2001 COSPAR. Published by Elsevier Science Ltd., Printed in Great Britain.

26. Christopher F. Chyba* and Cynthia B. Phillips, "Possible ecosystems and the search for life on Europa,” PERSPECTIVE, Proceedings of the National Academy of Sciences (PNAS), USA, January 30, 2001 u vol. 98,no. 3, pp. 801-804.

27. Thomas B. McCord, Gary B. Hansen, and Charles A. Hibbitts, "Hydrated Salt Minerals on Ganymede’s Surface: Evidence of an Ocean Below,” Science, 2001 May 25; 292: 1523-1525.

28. T.B. McCord, R.W. Carlson, W.D. Smythe, G.B. Hansen, R.N. Clark, C.A. Hibbitts, F.P. Fanale, J.C. Granahan, M. Segura, D.L. Matson, T.V. Johnson, and P.D. Martin, "Organics and Other Molecules in the Surfaces of Callisto and Ganymede,” Science, 1997 October 10; 278: 271-275.

29. Adam P. Showman and and Renu Malhotra, "The Galilean Satellites," Science 1999 October 1; 286: 77-84.

30. R. Carlson, W. Smythe, K. Baines, E. Barbinis, K. Becker, R. Burns, S. Calcutt, W. Calvin, R. Clark, G. Danielson, A. Davies, P. Drossart, T. Encrenaz, F. Fanale, J. Granahan, G. Hansen, P. Herrera, C. Hibbitts, J. Hui, P. Irwin, T. Johnson, L. Kamp, H. Kieffer, F. Leader, E. Lellouch, R. Lopes-Gautier, D. Matson, T. McCord, R. Mehlman, A. Ocampo, G. Orton, M. Roos-Serote, M. Segura, J. Shirley, L. Soderblom, A. Stevenson, F. Taylor, J. Torson, A. Weir, and P. Weissman, "Near-Infrared Spectroscopy and Spectral Mapping of Jupiter and the Galilean Satellites: Results from Galileo's Initial Orbit,” Science, 1996 October 18; 274: 385-388.

31. R.W. Carlson, M.S. Anderson, R.E. Johnson, W.D. Smythe, A.R. Hendrix, C.A. Barth, L.A. Soderblom, G.B. Hansen, T.B. McCord, J.B. Dalton, R.N. Clark, J.H. Shirley, A.C. Ocampo, and D.L. Matson, “Hydrogen Peroxide on the Surface of Europa," Science 1999 March 26; 283: 2062-2064.

32. Amanda E. Lowell, Kah-Siew Ho, and Robert A. Lodder, "Remote Hyperspectral Imaging of Endolithic Biofilms Using a Robotic Probe,” Contact in Context:v1i1/planetprobe, Copyright 2002 Contact in Context. This article is available at http://cic.setileague.org/v1i1/planetprobe.pdf

33. Frank D. Carsey, Gun-Shing Chen, James Cutts, Lloyd French, Roger Kern, A., Lonne Lane, Paul Stolorz, and Wayne Zimmerman, and Phil Ballou Exploring Europa's Ocean: A Challenge For Marine Technology Of This Century,” JPL 00-0221, Marine Technology Society Journal, Deep Ocean Frontiers Issue, Washington D.C., USA, 2000. http://techreports.jpl.nasa.gov/2000/00-0221.pdf

34. David F. Woerner, "Revolutionary Systems And Technologies For Missions To The Outer Planets," Advanced Scientific Space Missions, Aosta, Italy, June 29-July 1, 1998. http://techreports.jpl.nasa.gov/1998/98-0522.pdf

35. Palaszewski, B., "Atmospheric Mining in the Outer Solar System: Mission Scenarios and Options for In-Situ Resource Utilization,” AIAA-2007-5598, July 2007.

36. Palaszewski, B., “Atmospheric Mining in the Outer Solar System: Vehicle Design Issues,” AIAA 2006-5222, July 2006.

37. Palaszewski, B., “Atmospheric Mining in the Outer Solar System,” AIAA 2005-4319, July 2005.

38. Andrews, D.G. (Boeing Co., Seattle, Wash.) Bloetscher, F. (Goodyear Aerospace Corp., Akron, Ohio), “Aerobraked Orbital Transfer Vehicle Definition,” AIAA-1981-279, January 1981, 9 p.

39. R. Dyke, Swales Aerospace, Hampton, VA, and G. Hrinda, NASA Langley Research Center, Hampton, VA, "Structural Design For A Neptune Aerocapture Mission,” AIAA-2004-5179, August, 2004. 
Viking 1/2 Pathfinder MER A/B Phoenix MSL

\begin{tabular}{|c|c|c|c|c|c|}
\hline Diameter, m & 3.5 & 2.65 & 2.65 & 2.65 & 4.5 \\
\hline Entry mass, kg & 930 & 585 & 840 & 602 & $>3000$ \\
\hline Landed mass, kg & 603 & 360 & 539 & 364 & $>1700$ \\
\hline Landing altitude, km & -3.5 & -1.5 & -1.3 & -3.5 & -1.0 \\
\hline Landing ellipse, km & $420 \times 200$ & $100 \times 50$ & $80 \times 20$ & $75 \times 20$ & $<10 \times 10$ \\
\hline Relative entry velocity, $\mathrm{km} / \mathrm{s}$ & $4.5 / 4.42$ & 7.6 & 5.5 & 5.9 & $>5.5$ \\
\hline Relative entry FPA, deg & $\begin{array}{c}-17.6 \\
64\end{array}$ & $\begin{array}{c}-13.8 \\
62\end{array}$ & $\begin{array}{c}-11.5 \\
90\end{array}$ & $\begin{array}{l}-13 \\
65\end{array}$ & $\begin{array}{l}-15.2 \\
>140\end{array}$ \\
\hline $\begin{array}{l}\mathrm{m} / \mathrm{C}_{\mathrm{D}} \mathrm{S}_{\text {ref, }} \mathrm{kg} / \mathrm{m}^{2} \\
\text { Turbulent at peak heating? }\end{array}$ & $\begin{array}{l}64 \\
\text { No }\end{array}$ & $\begin{array}{l}62 \\
\text { No }\end{array}$ & $\begin{array}{l}90 \\
\text { No }\end{array}$ & $\begin{array}{l}65 \\
\text { No }\end{array}$ & $\begin{array}{l}>140 \\
\text { Yes }\end{array}$ \\
\hline Peak heat flux, W/cm 2 & 24 & 115 & 54 & 56 & $>200$ \\
\hline Peak surface pressure, atm & 0.10 & 0.20 & 0.10 & 0.12 & $>0.3$ \\
\hline Heatshield TPS material & SLA-561V & SLA-561V & SLA-561V & SLA-561V & SLA-561V \\
\hline Backshield TPS material & None & SLA-561S & SLA-561S & SLA-561S & SLA-561S \\
\hline Hypersonic $\alpha$, deg & -11 & 0 & 0 & 0 & -16 \\
\hline Hypersonic L/D & 0.18 & 0 & 0 & 0 & 0.24 \\
\hline Control & 3-axis & Spinning & Spinning & 3-axis & 3 -axis \\
\hline Guidance & No & No & No & No & Yes \\
\hline
\end{tabular}

Figure 1.-Comparison of Viking-spacecraft-like (sphere-cone) aeroshells for Mars entry (Ref. 1). 

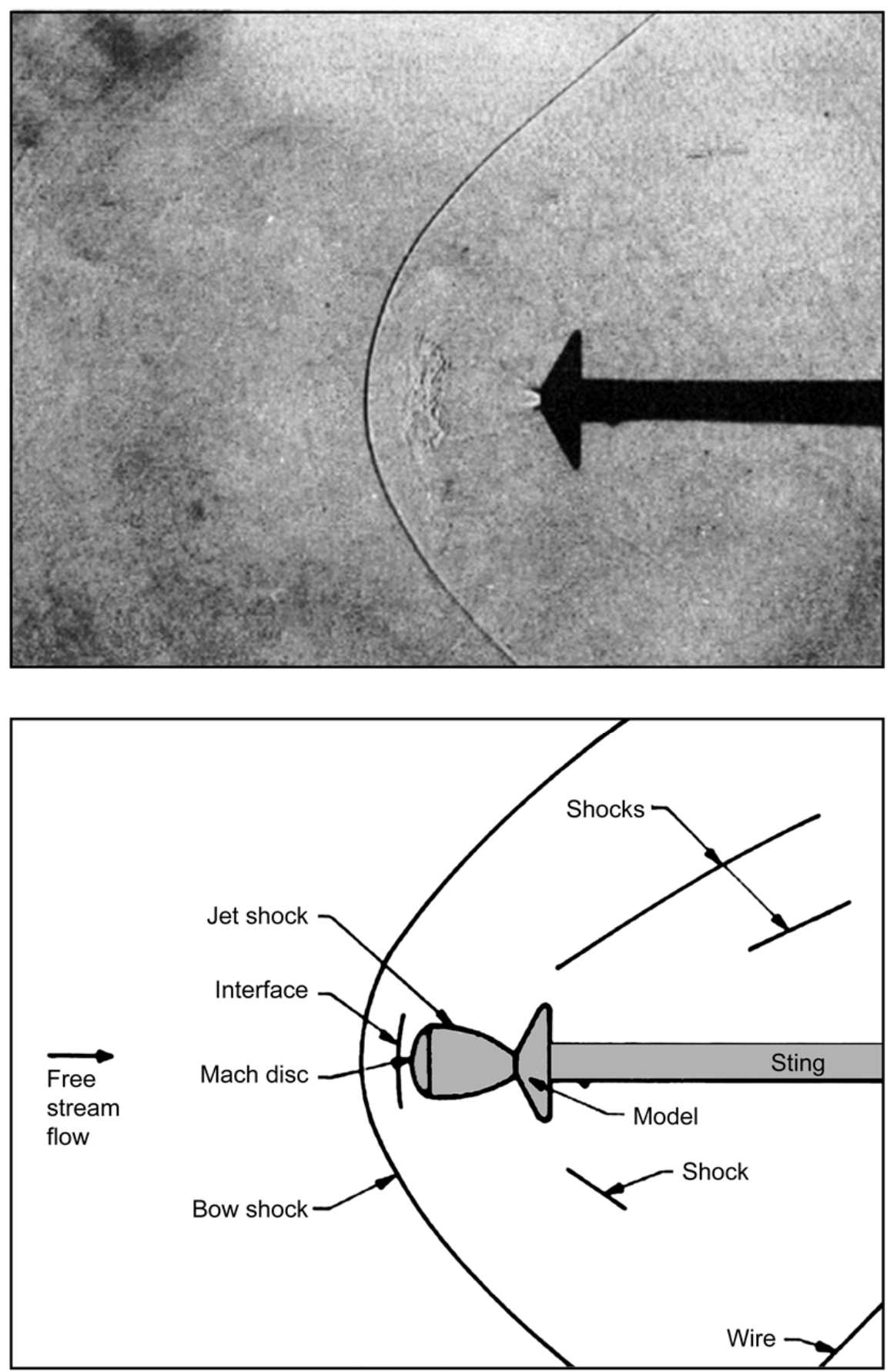

Figure 2.-Historical retro-propulsion testing (Ref. 3, 1970). Single nozzle $60^{\circ}$ aeroshell model with blunt flow interaction, $\mathrm{M}_{\infty}=2.0, \mathrm{C}_{\mathrm{T}}=1.1$ 


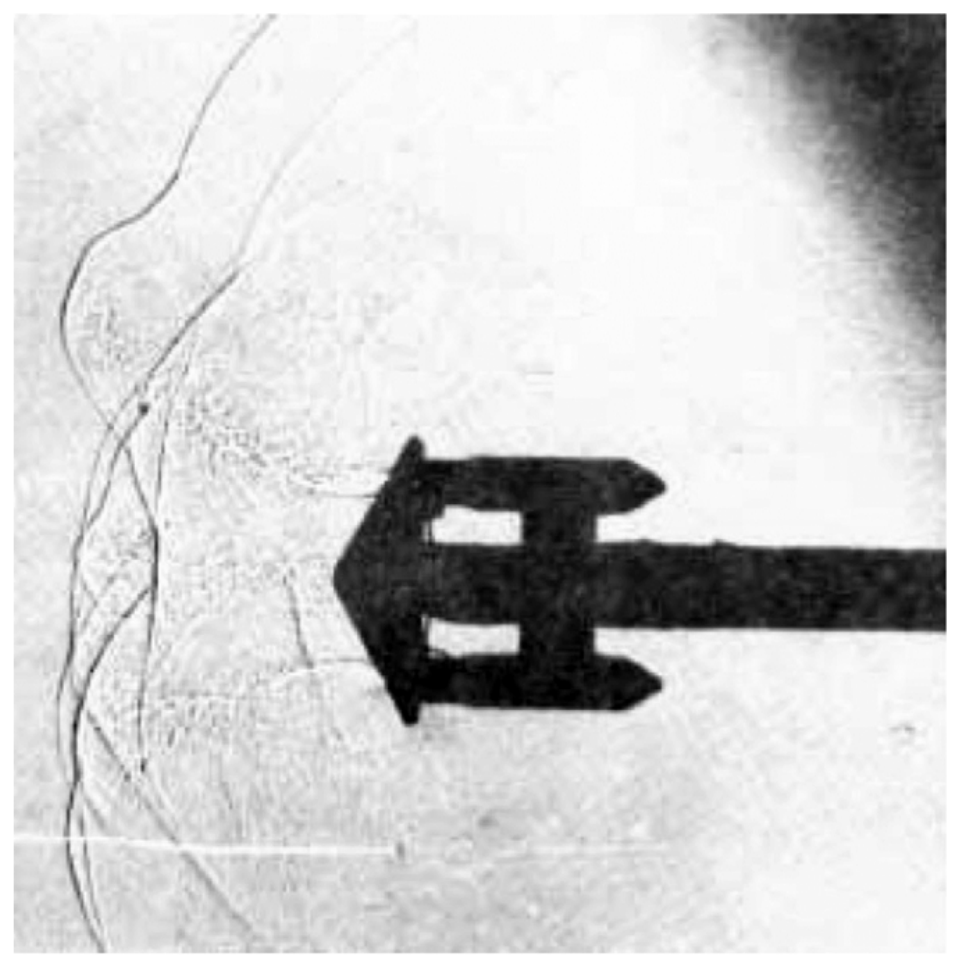

Figure 3.-Historical retro-propulsion testing, three engine configuration (Ref. 3, 1970).

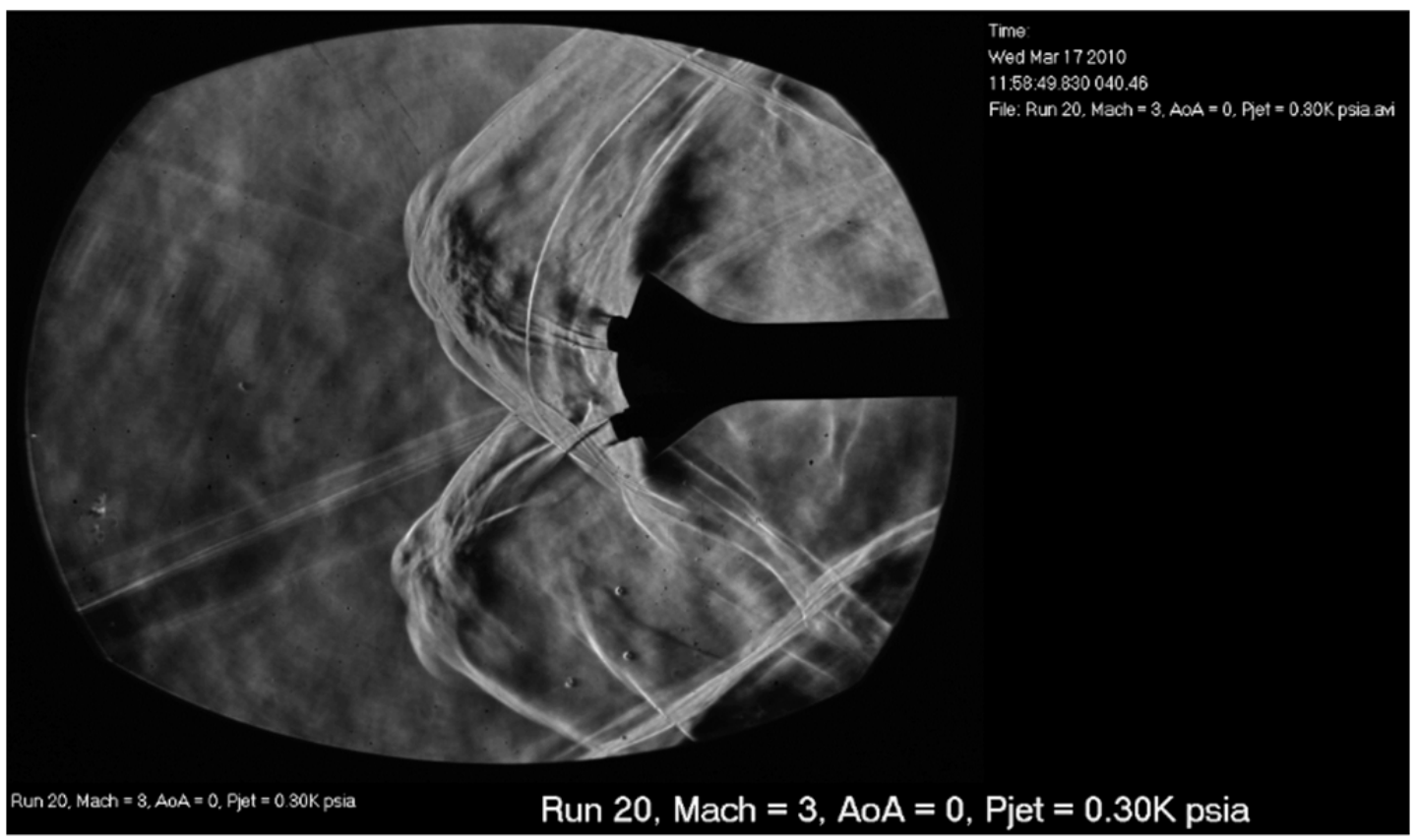

Figure 4.-Schlieren image from $1 \times 1$ SWT testing - three engine model, Mach $=3.0, \mathrm{Re} / \mathrm{ft}=1.45 \times 10^{6}$, and $P$, total $(\mathrm{psi})=8.67, \mathrm{AoA}=0$ degrees, 300 psia engine chamber pressure . 


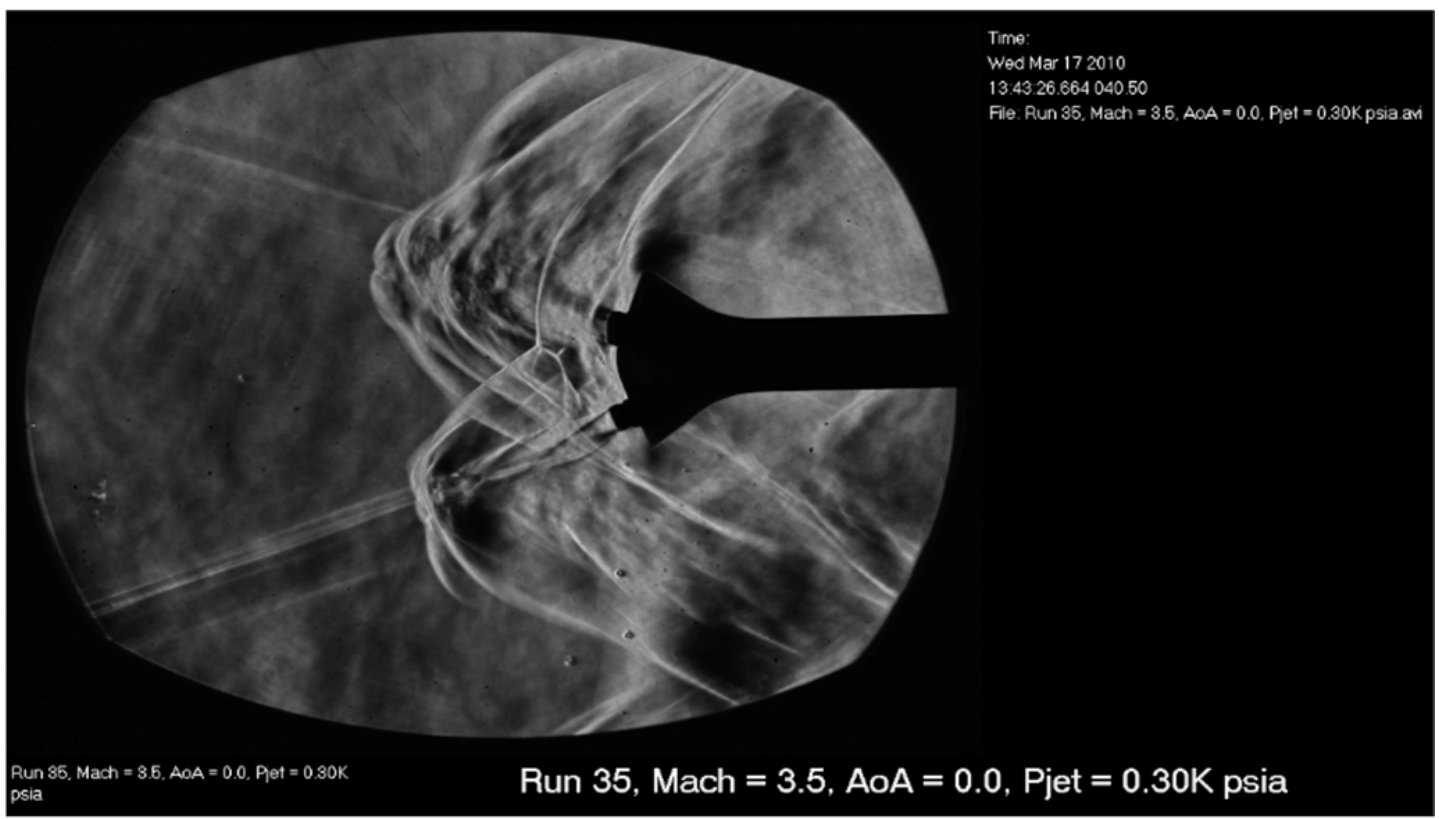

Figure 5.-Schlieren image from $1 \times 1$ SWT testing - three engine model, Mach $=3.5, \mathrm{Re} / \mathrm{ft}=1.86 \times 10^{6}$, and $P$, total $(\mathrm{psi})=15.00, \mathrm{AoA}=0$ degrees, 300 psia engine chamber pressure.

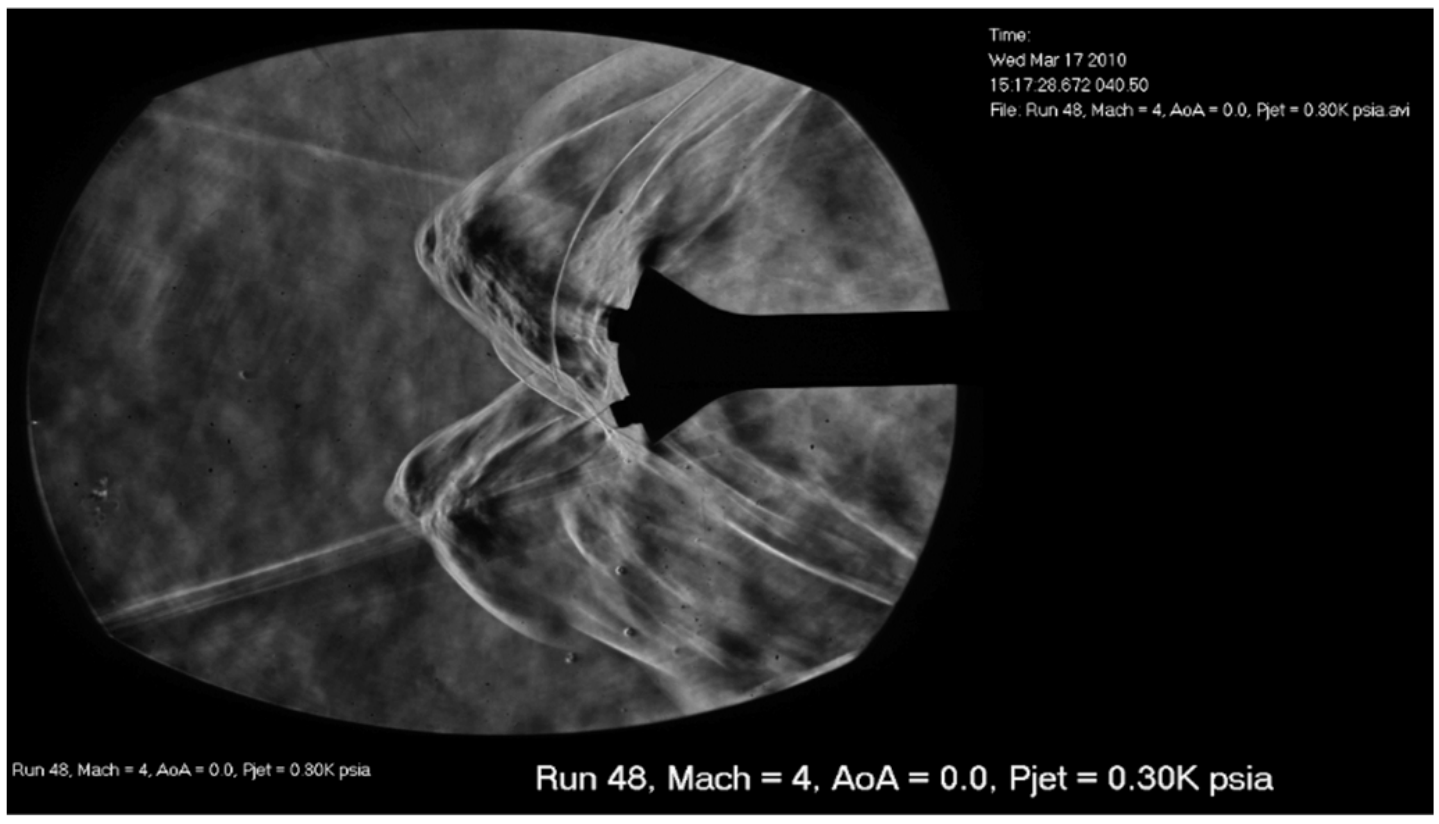

Figure 6.-Schlieren image from $1 \times 1$ SWT testing - three engine model, Mach $=4.0$, Re/ft $=2.58 \times 10^{6}$, and $P$, total $(p s i)=26.13, A o A=0$ degrees, 300 psia engine chamber pressure . 


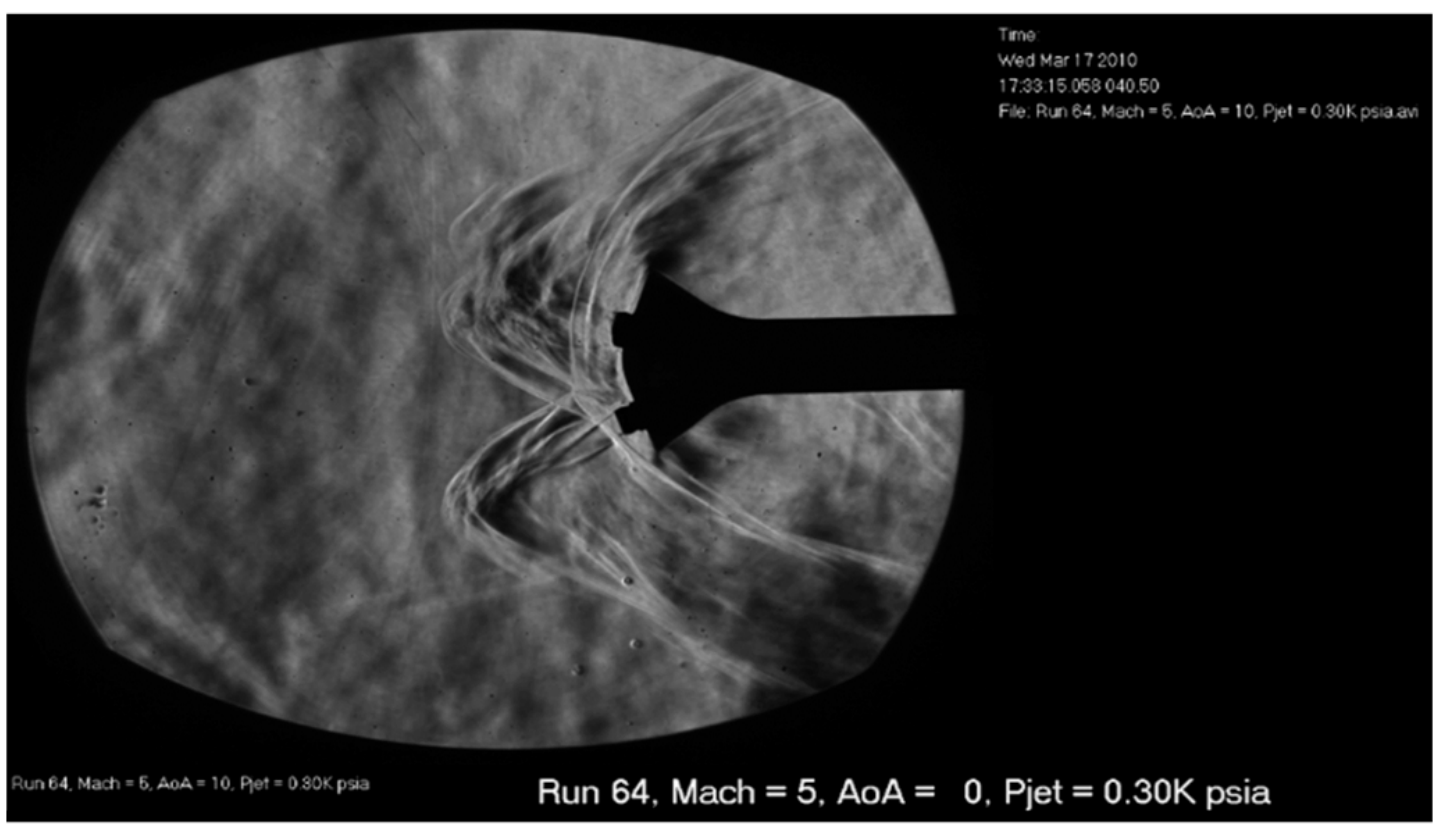

Figure 7.-Schlieren image from $1 \times 1 \mathrm{SWT}$ testing - three engine model, Mach $=5.0, \mathrm{Re} / \mathrm{ft}=5.19 \times 10^{6}$, and $P$, total $(p s i)=92.39, A o A=0$ degrees, 300 psia engine chamber pressure .

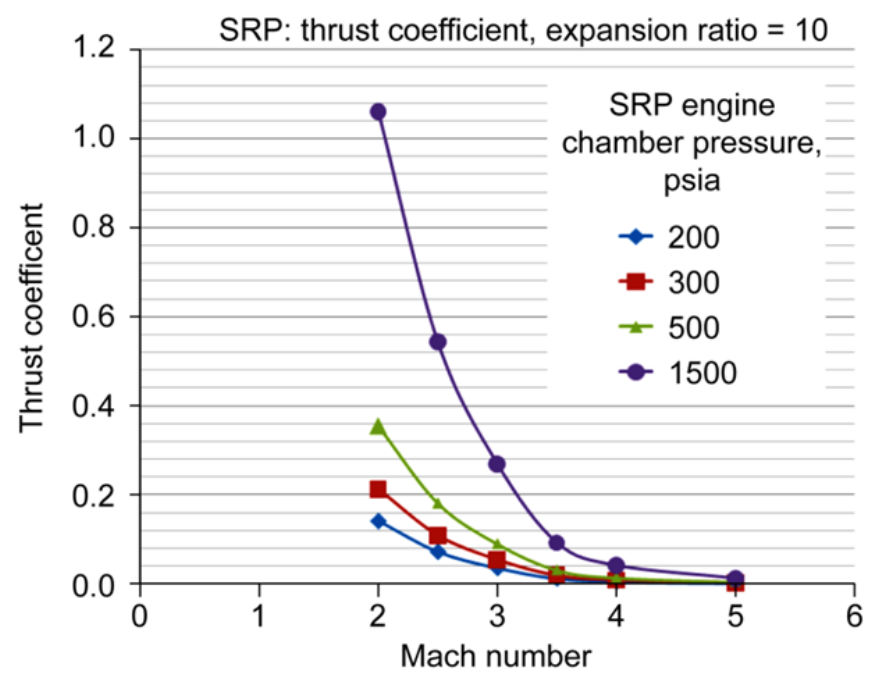

Figure 8.-Thrust coefficient versus Mach Number for varying engine chamber pressures. 


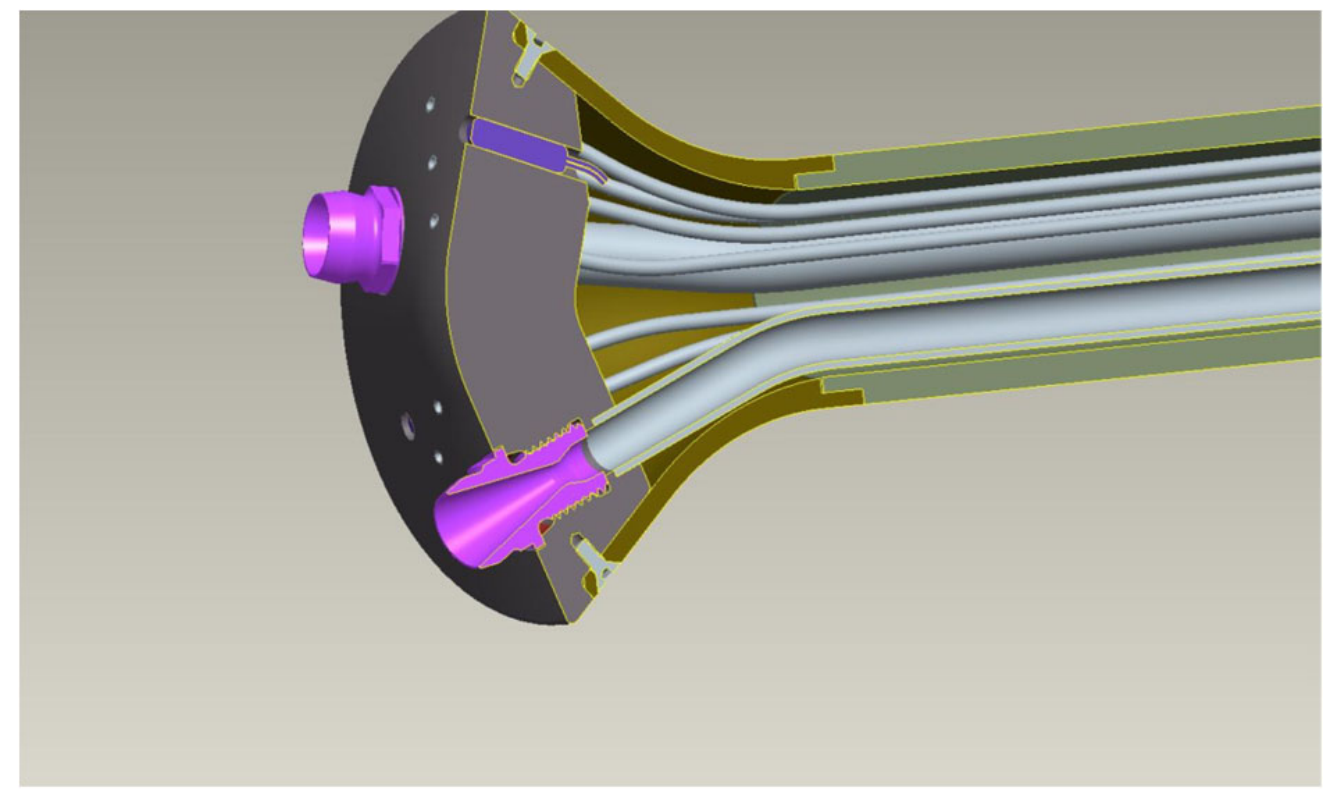

Figure 9.-Retro-propulsion model for three engine configuration, with nozzle extensions (expansion ratio $=10: 1)$.

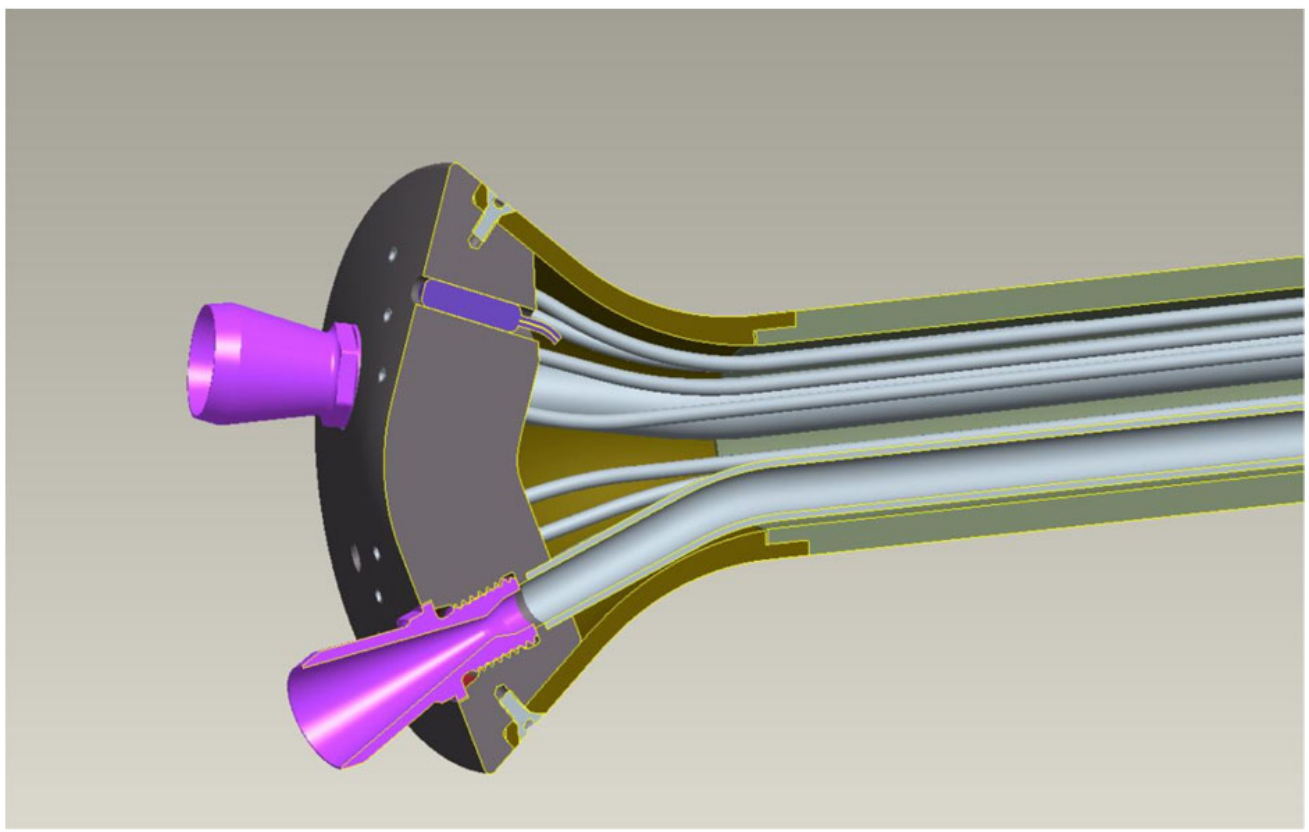

Figure 10.-Retro-propulsion model for three engine configuration, with nozzle extensions (expansion ratio $=20: 1)$. 


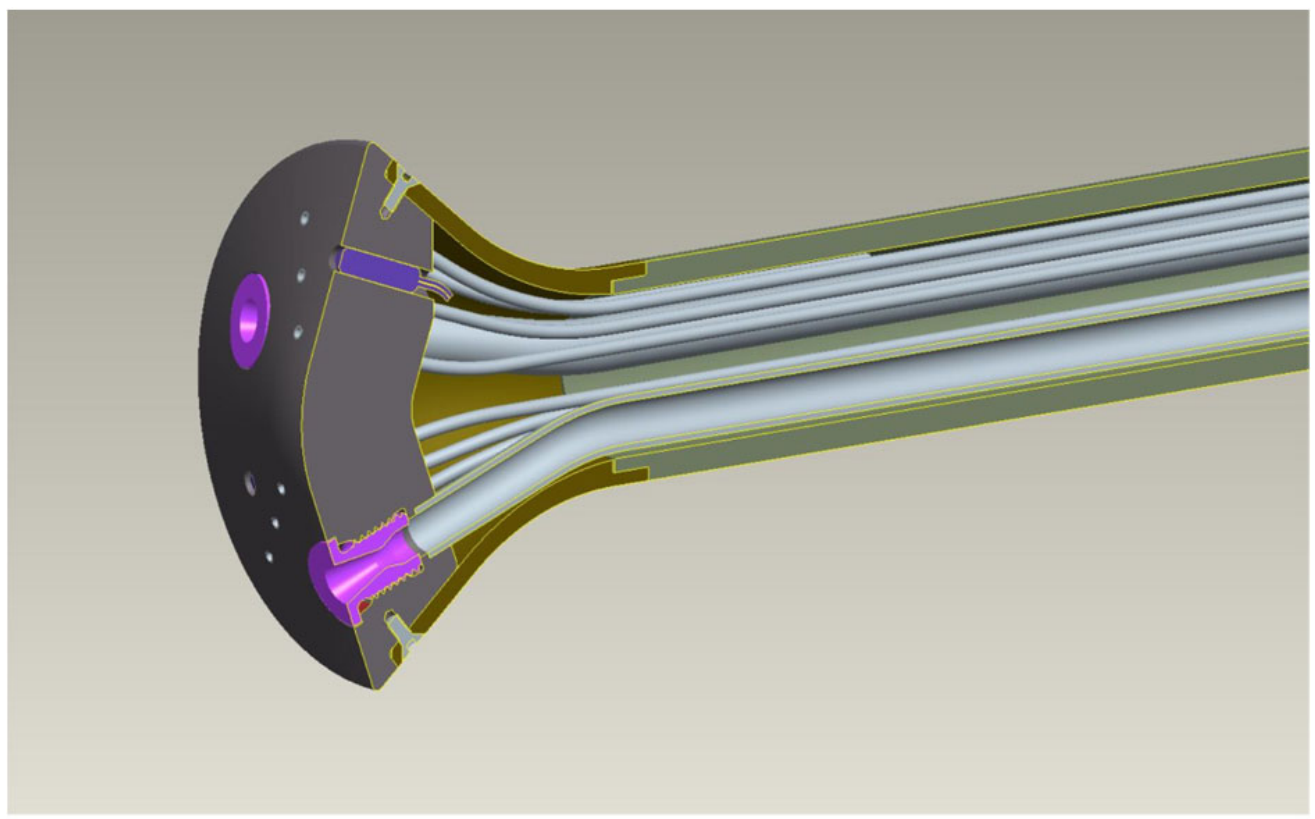

Figure 11.-Retro-propulsion model for three engine configuration, with no nozzle extensions $($ expansion ratio $=4: 1)$. 
TABLE I.-OVERALL RESULTS OF AND COMMENTS ON EDL SRP TEST MATRIX [2.5 in. diameter aeroshell model, three engine configuration.]




Launch escape system (CAC) diagram
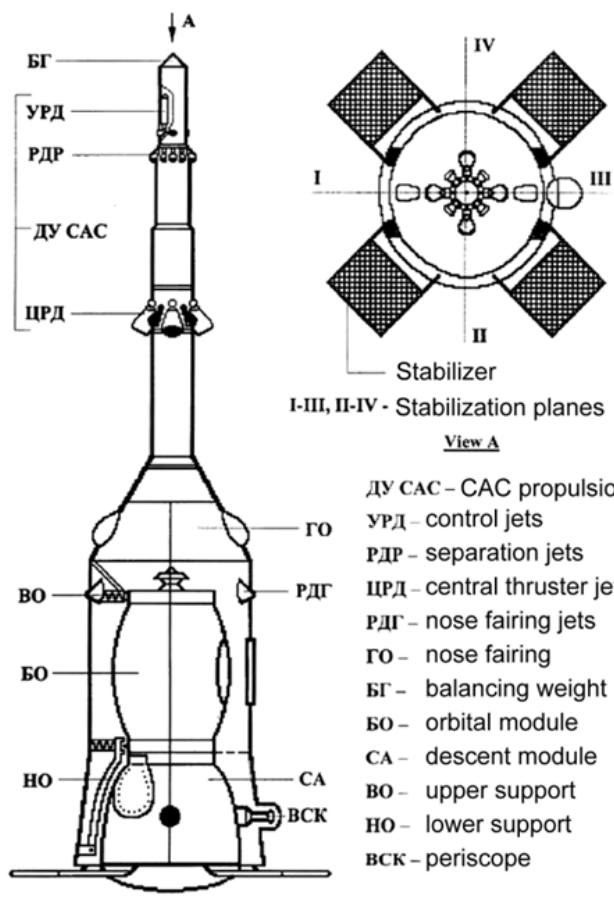

ду CAC-CAC propulsion system; УРД-control jets

PIP - separation jets

ЦРД- central thruster jets

$\mathrm{P} \mathrm{LI}$ - nose fairing jets

ro - nose fairing

$\mathbf{6 \Gamma}$ - balancing weight

50 - orbital module

CA - descent module

BO - upper support

HO - lower support

вск- periscope

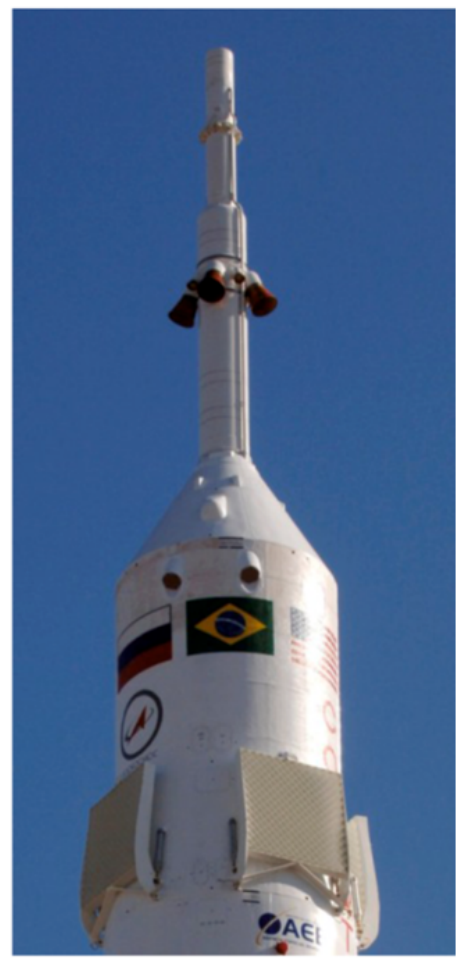

Figure 12.-Grid fins used in Russian Soyuz Launch Escape System (Ref. 9).

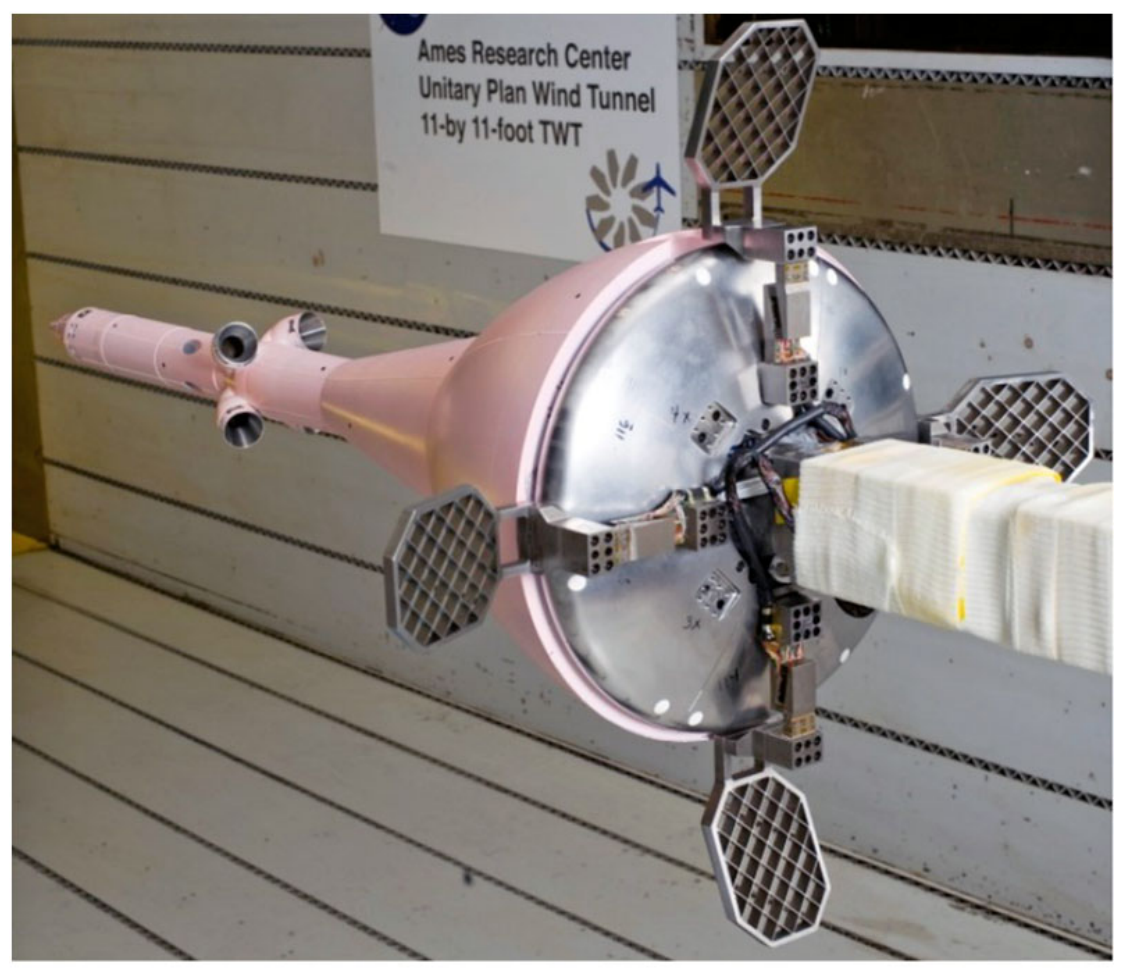

Figure 13.-Grid fins used in Orion Launch Abort System Subscale Testing (Ref. 9, Orion testing). 


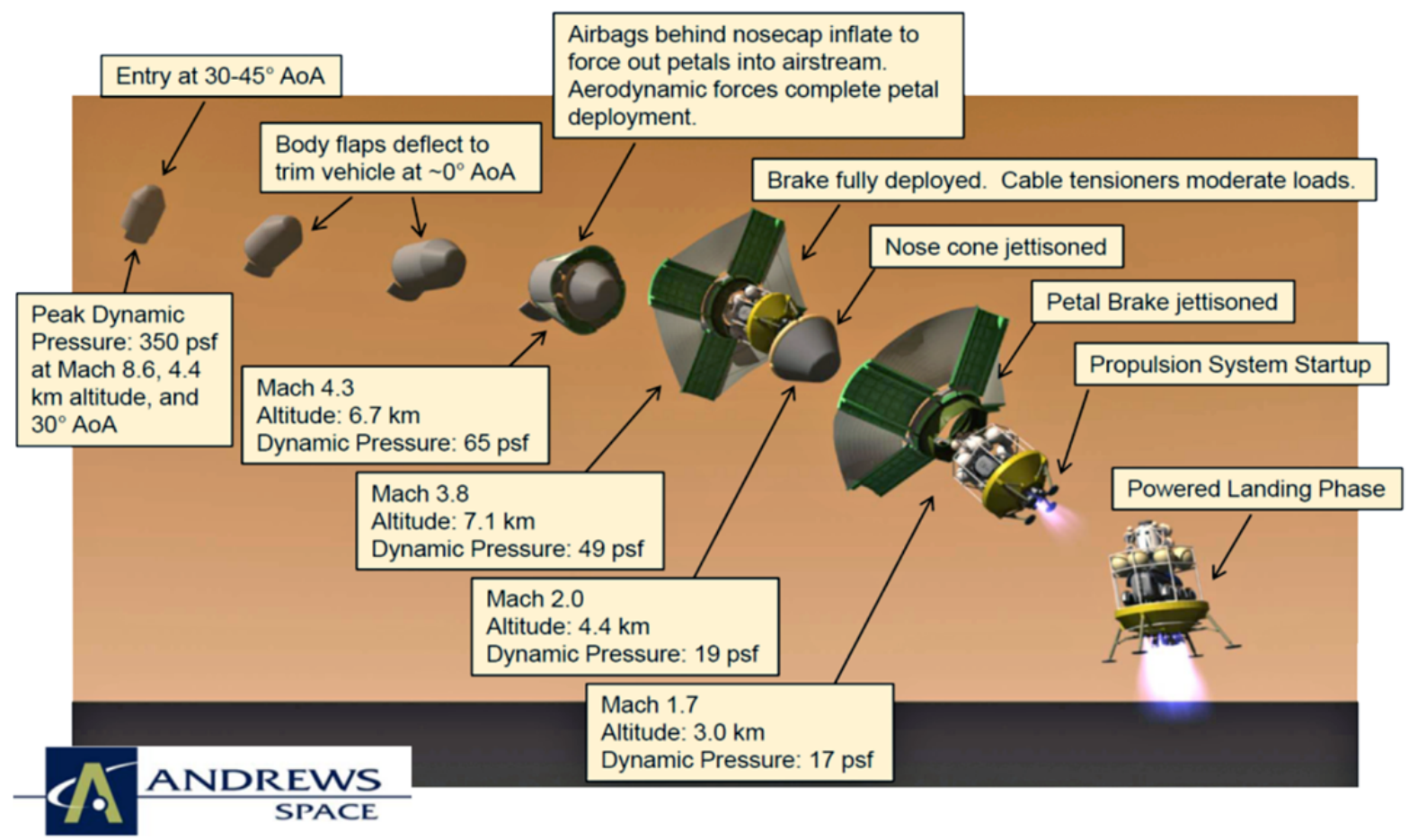

Figure 14.-Petal brake for Mars EDL (Ref. 22). 


\section{Appendix $\mathrm{A}-\mathrm{AoA}=10^{\circ}\left(15^{\circ}\right.$, in some cases $), 300$ psia Chamber Pressure}

A1. $A o A=0^{\circ} 500$ psia chamber pressure

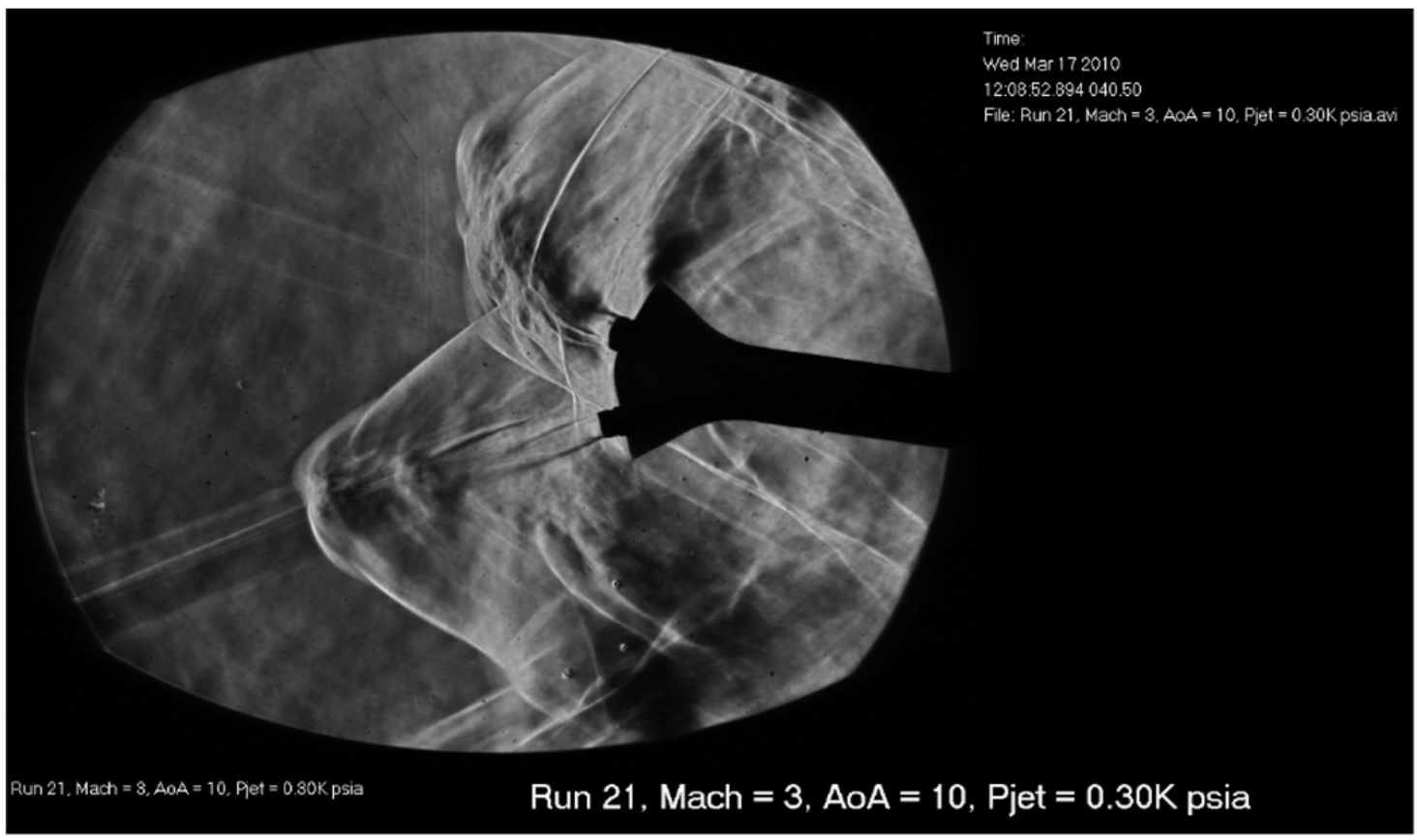

Figure A1-1.-Schlieren image from $1 \times 1$ SWT testing - three engine model, Mach $=3.0, \mathrm{Re} / \mathrm{ft}=1.42 \times 106$, and $\mathrm{P}$, total $(\mathrm{psi})=8.49, \mathrm{AoA}=10$ degrees, 300 psia engine chamber pressure.

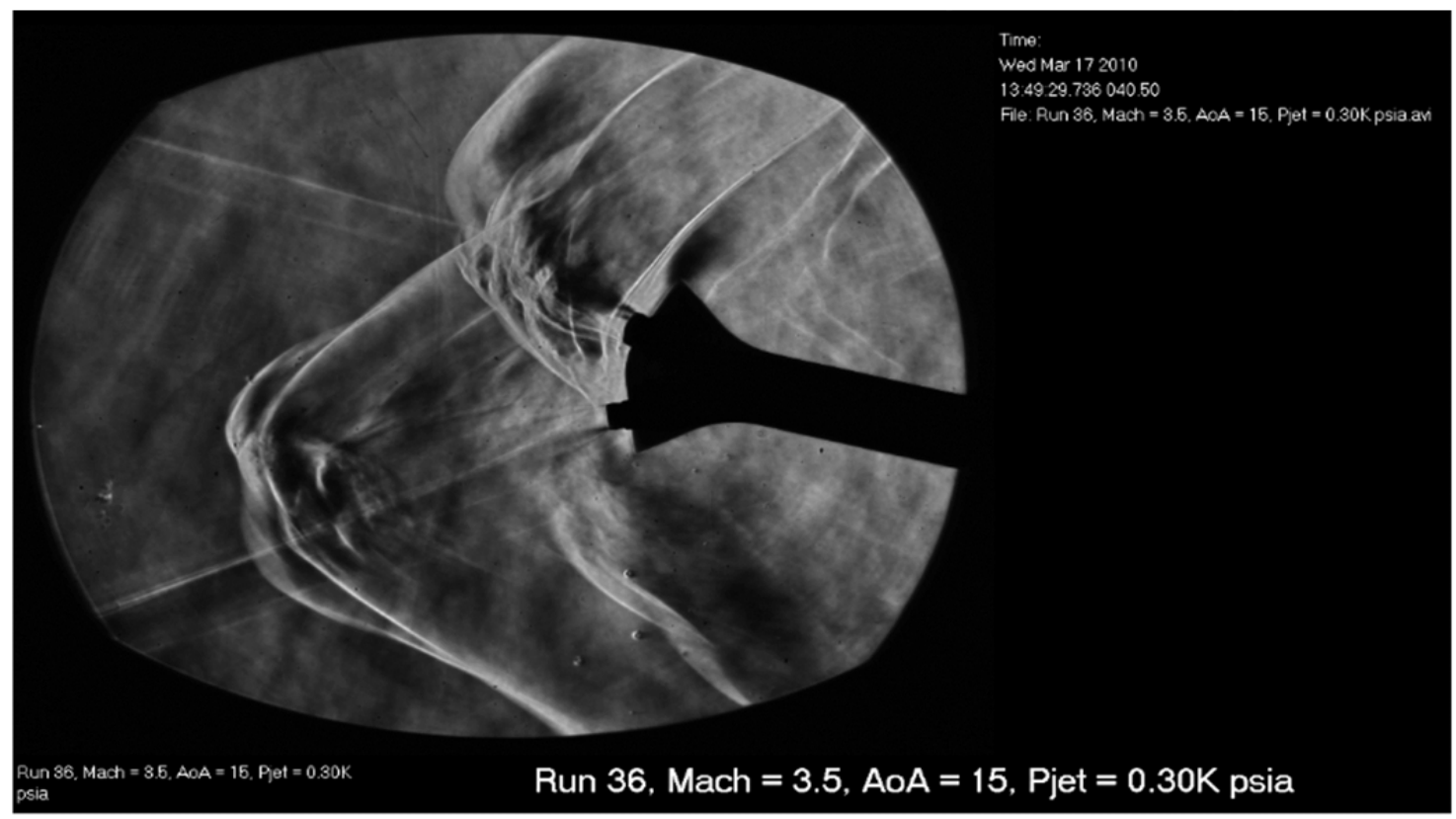

Figure A1-2.-Schlieren image from $1 \times 1$ SWT testing - three engine model, Mach $=3.5$, Re/ft $=1.87 \times 10^{6}$, and $P$, total $(p s i)=15.03, A o A=15$ degrees, 300 psia engine chamber pressure. 


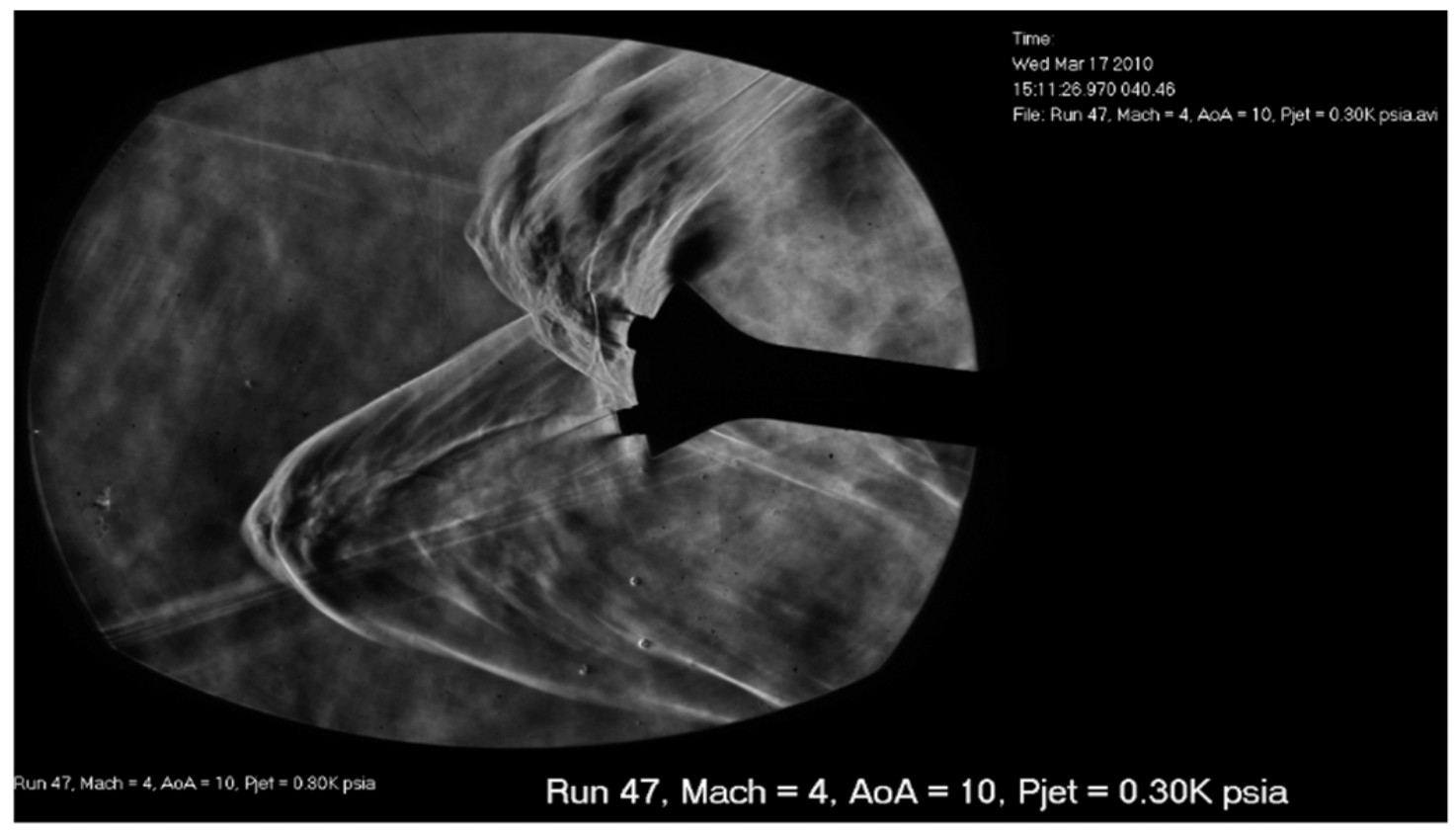

Figure A1-3.-Schlieren image from 1 $\times 1$ SWT testing - three engine model, Mach $=4.0, \mathrm{Re} / \mathrm{ft}=2.57 \times 106$, and $P$, total $(\mathrm{psi})=25.94, \mathrm{AoA}=10$ degrees, 300 psia engine chamber pressure.

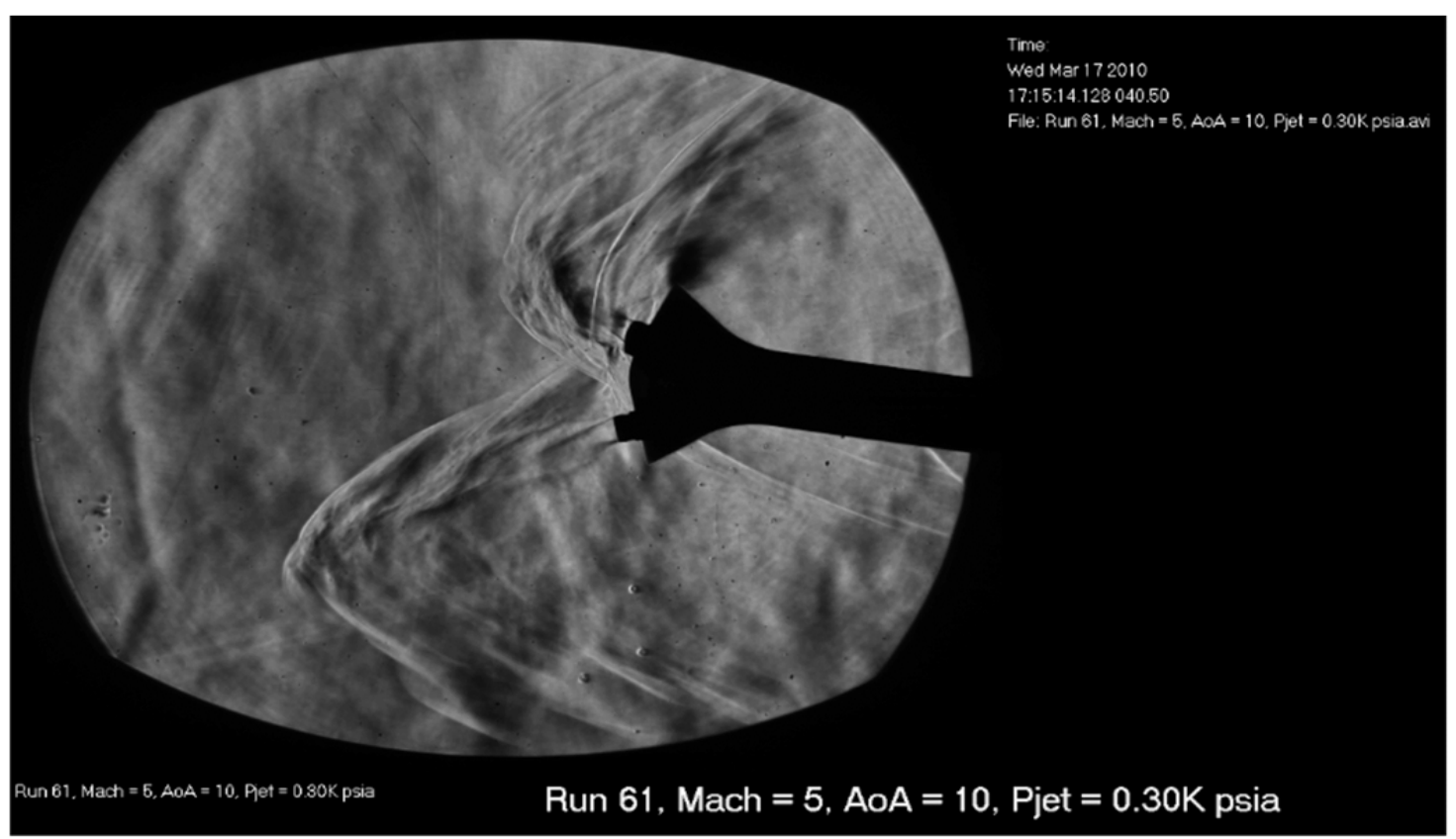

Figure A1-4.-Schlieren image from $1 \times 1 \mathrm{SWT}$ testing - three engine model, Mach $=5.0, \mathrm{Re} / \mathrm{ft}=5.32 \times 10^{6}$, and $P$, total $(\mathrm{psi})=90.37, \mathrm{AoA}=10$ degrees, 300 psia engine chamber pressure. 


\section{A2. $\mathrm{AoA}=10^{\circ} 500$ psia chamber pressure}

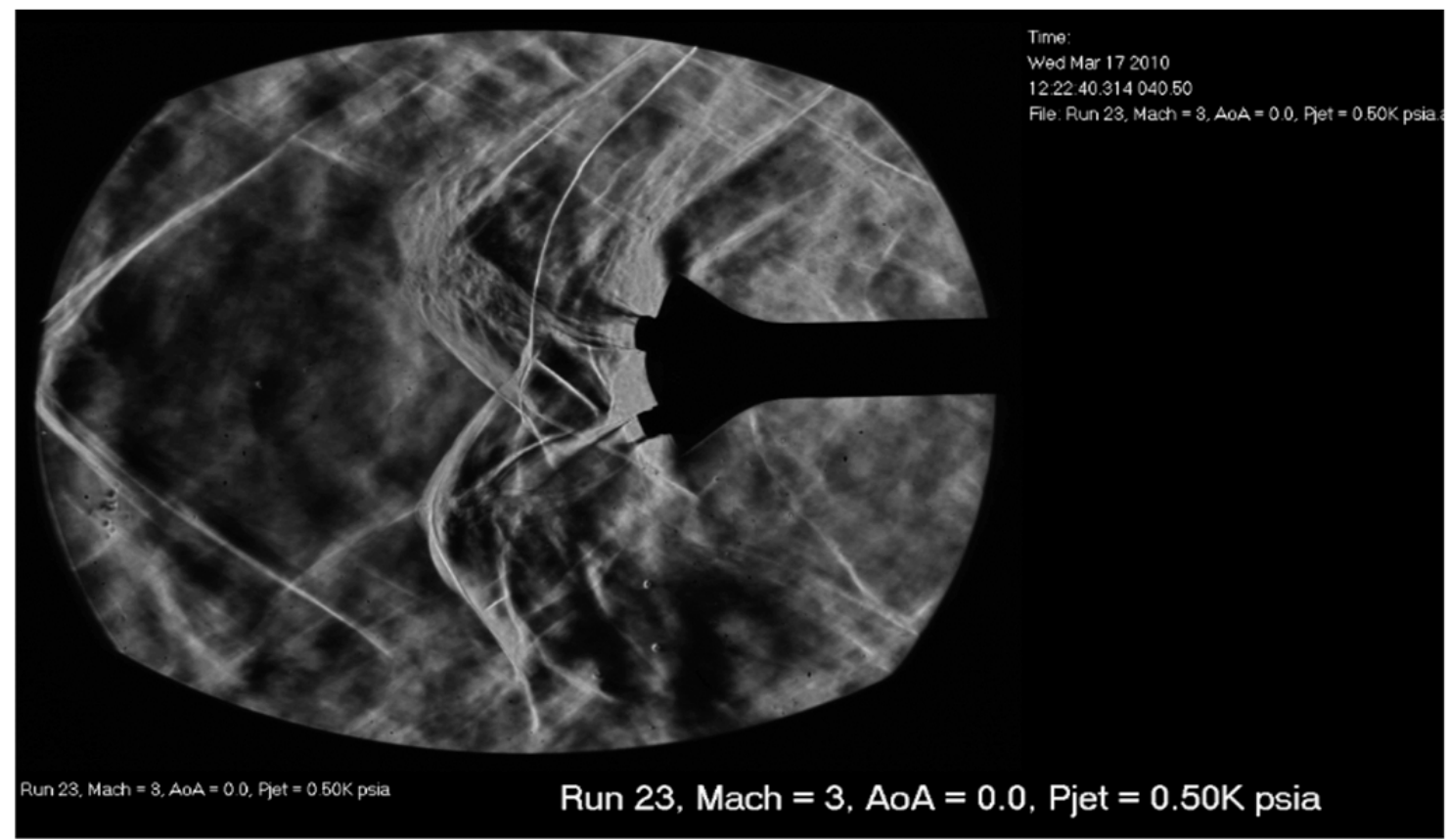

Figure A2-1.-Schlieren image from $1 \times 1$ SWT testing - three engine model, Mach $=3.0, \mathrm{Re} / \mathrm{ft}=1.50 \times 10^{6}$, and $\mathrm{P}$, total $(\mathrm{psi})=8.95, \mathrm{AoA}=0$ degrees, 500 psia engine chamber pressure, tunnel unstart.

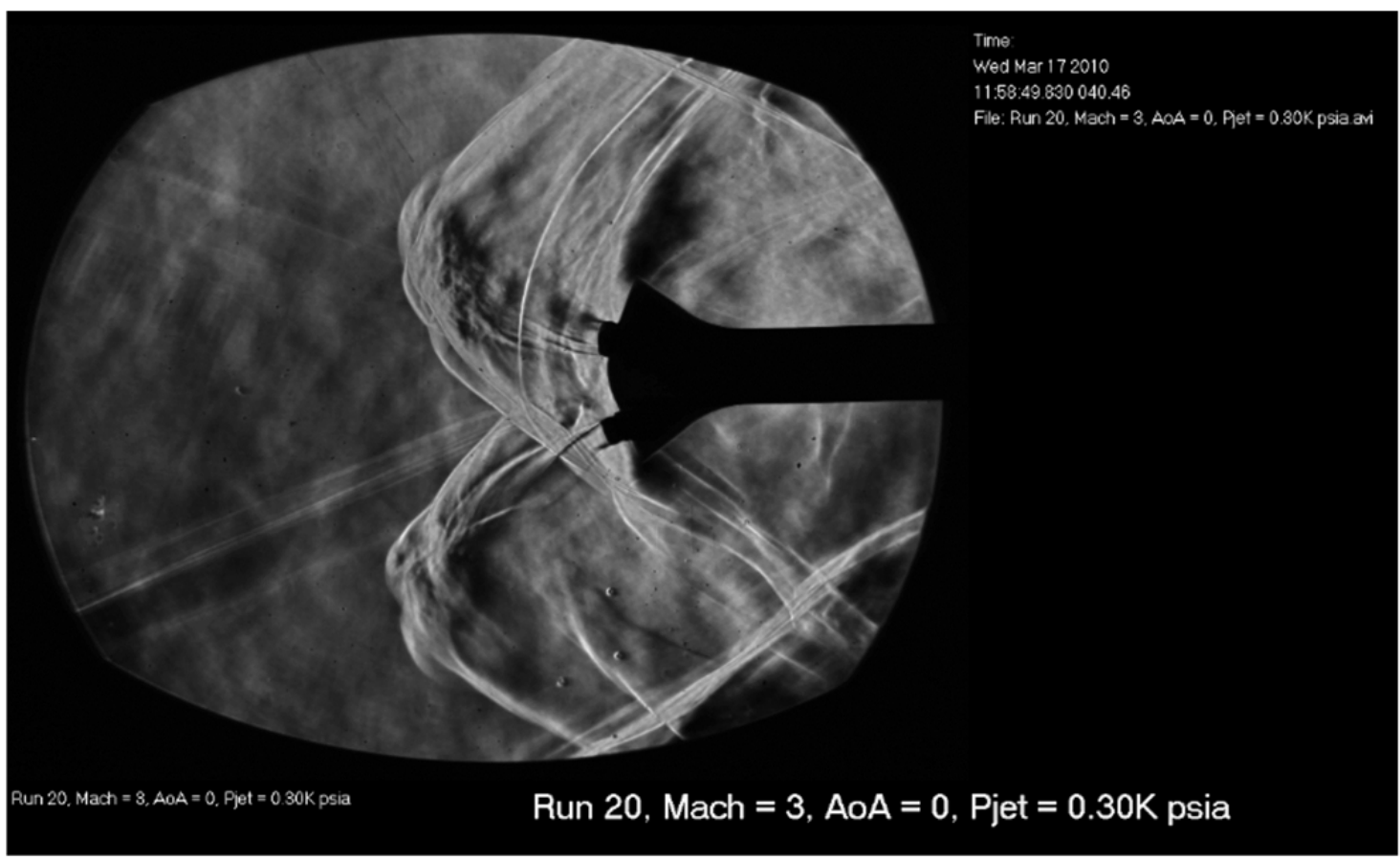

Figure A2-2.-Schlieren image from $1 \times 1 \mathrm{SWT}$ testing - three engine model, Mach $=3.5, \mathrm{Re} / \mathrm{ft}=1.45 \times 10^{6}$, and $\mathrm{P}$, total $(\mathrm{psi})=8.67, \mathrm{AoA}=0$ degrees, 500 psia engine chamber pressure. 


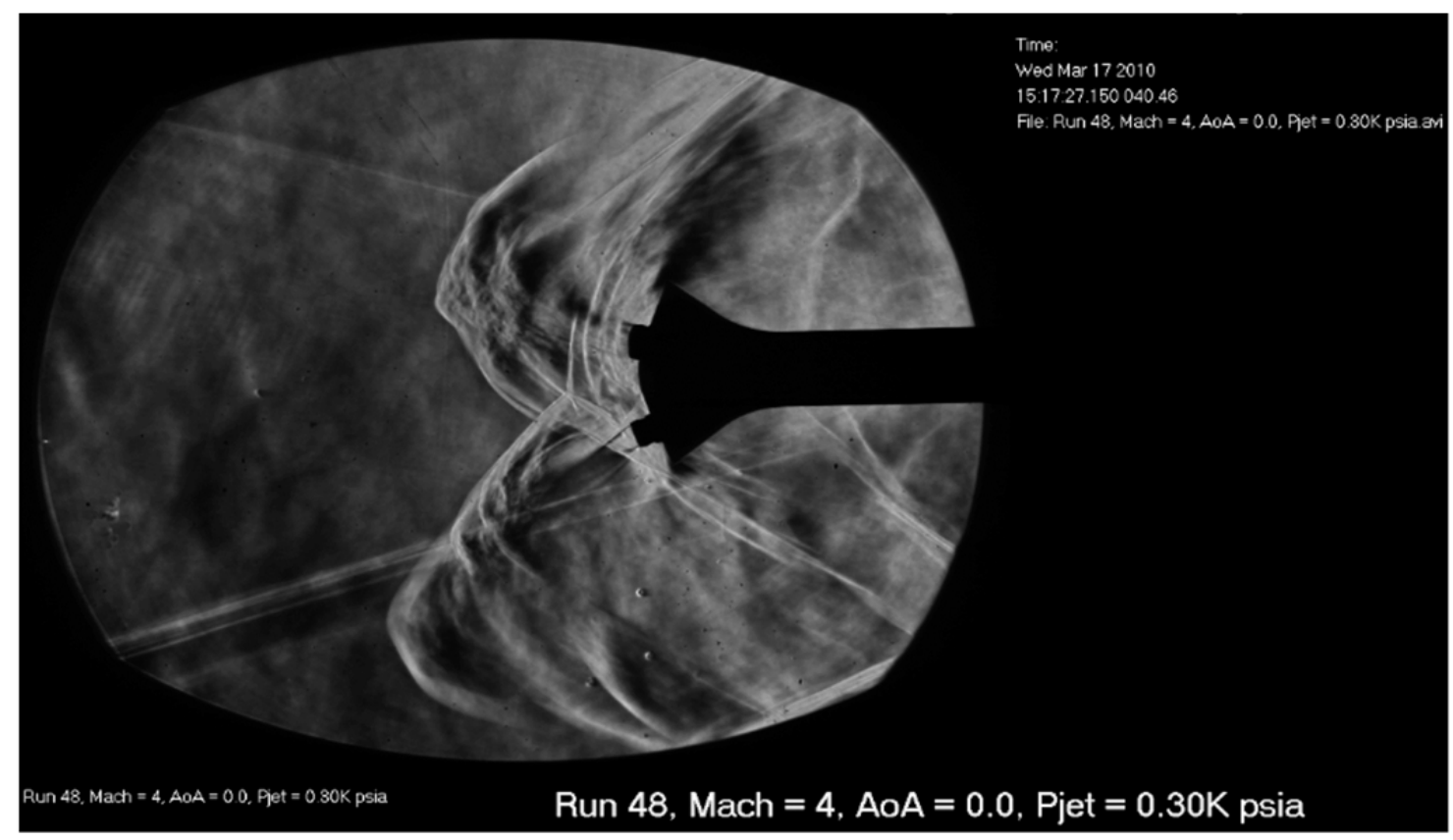

Figure A2-3.-Schlieren image from $1 \times 1$ SWT testing - three engine model, Mach $=4.0$, Re/ft $=2.60 \times 106$, and $\mathrm{P}$, total $(\mathrm{psi})=26.33, \mathrm{AoA}=0$ degrees, 500 psia engine chamber pressure.

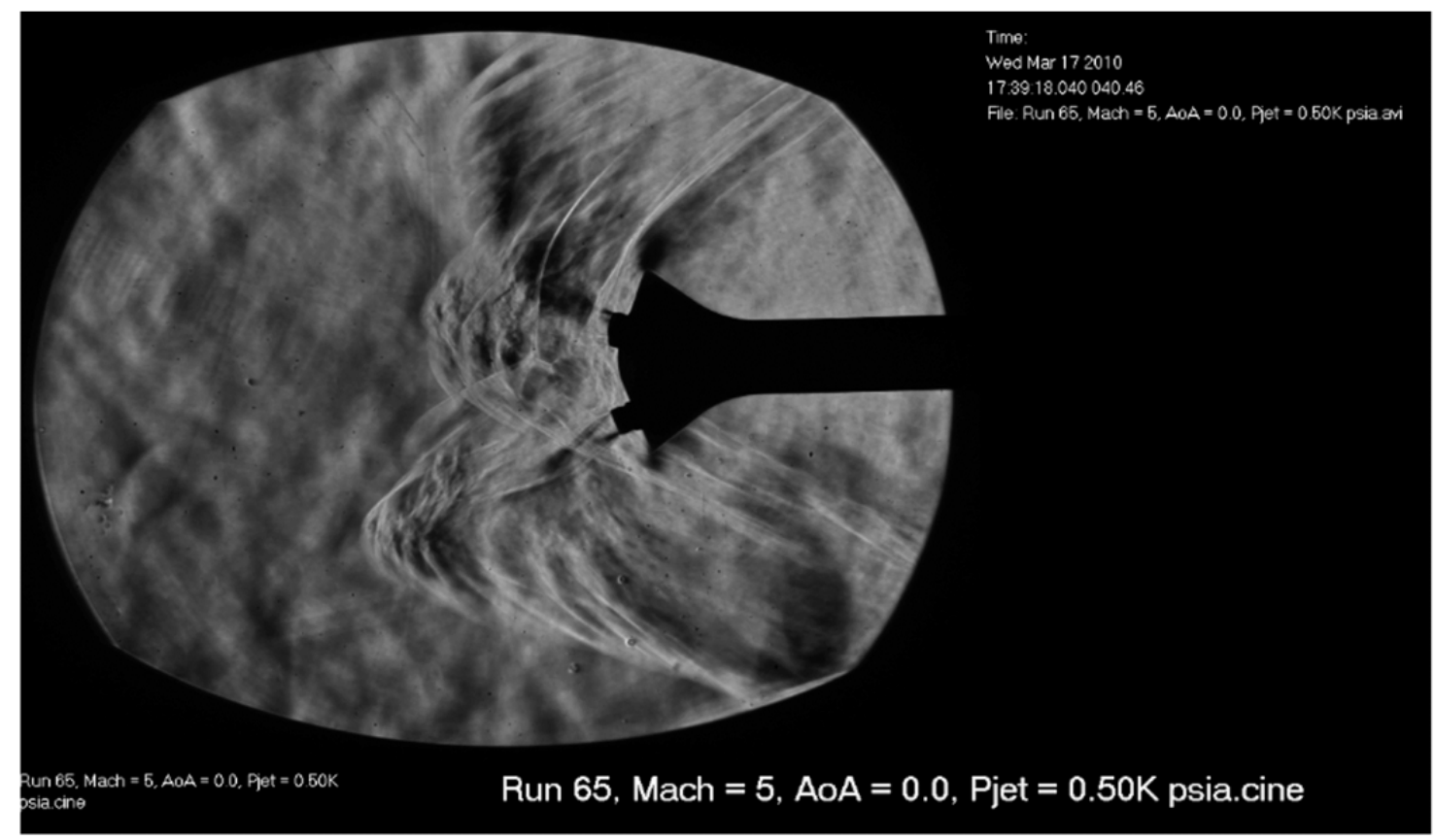

Figure A2-4.-Schlieren image from 1×1 SWT testing - three engine model, Mach $=5.0, \mathrm{Re} / \mathrm{ft}=4.91 \times 106$, and $\mathrm{P}$, total $(\mathrm{psi})=89.36, \mathrm{AoA}=0$ degrees, 500 psia engine chamber pressure. 


\section{A3. $\mathrm{A0A}=10^{\circ}, 500$ psia chamber pressure}

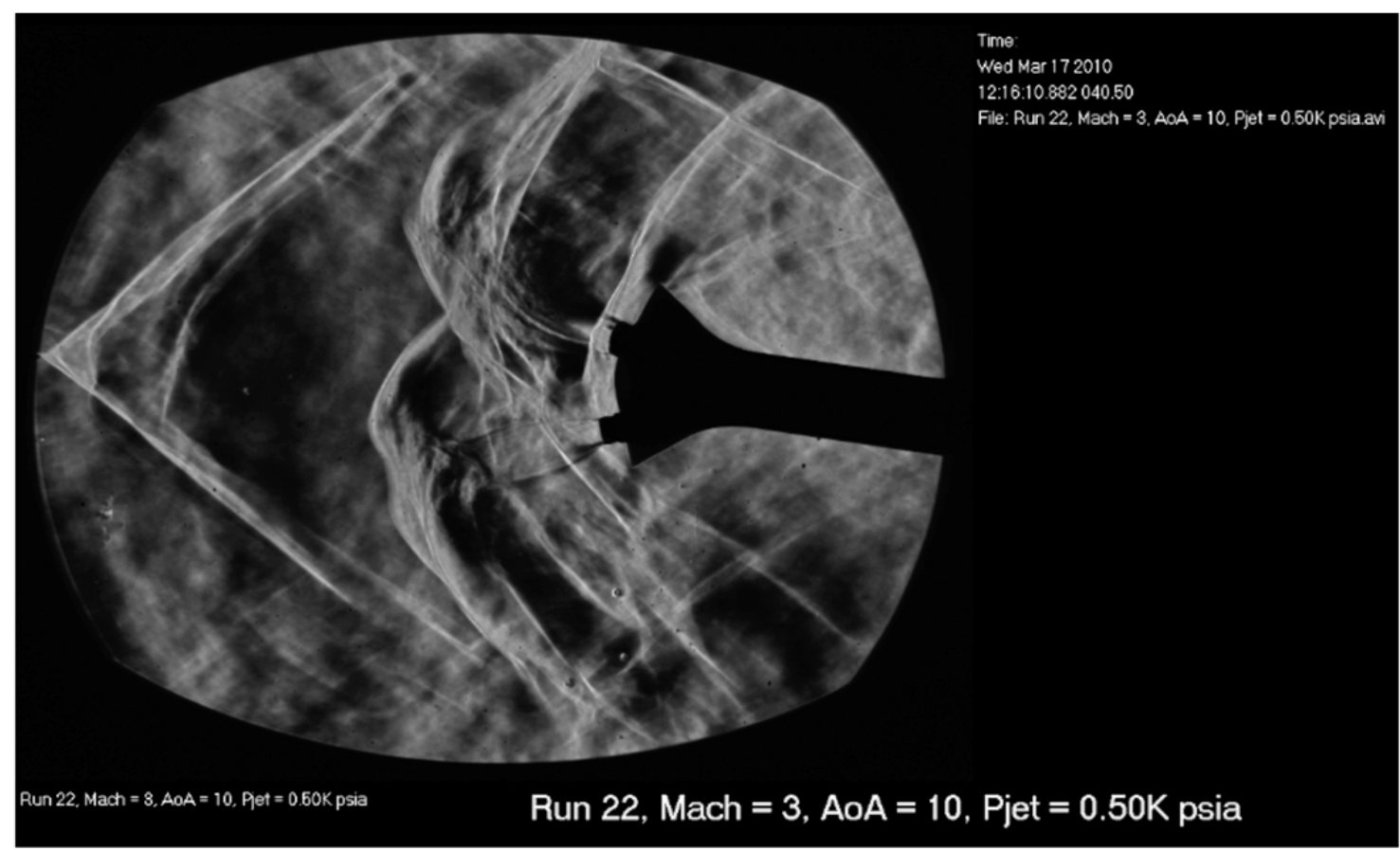

Figure A3-1.-Schlieren image from $1 \times 1 \mathrm{SWT}$ testing - three engine model, Mach $=3.0, \mathrm{Re} / \mathrm{ft}=1.44 \times 10^{6}$, and $\mathrm{P}$, total $(\mathrm{psi})=8.66, \mathrm{AoA}=10$ degrees, 500 psia engine chamber pressure, tunnel unstart.

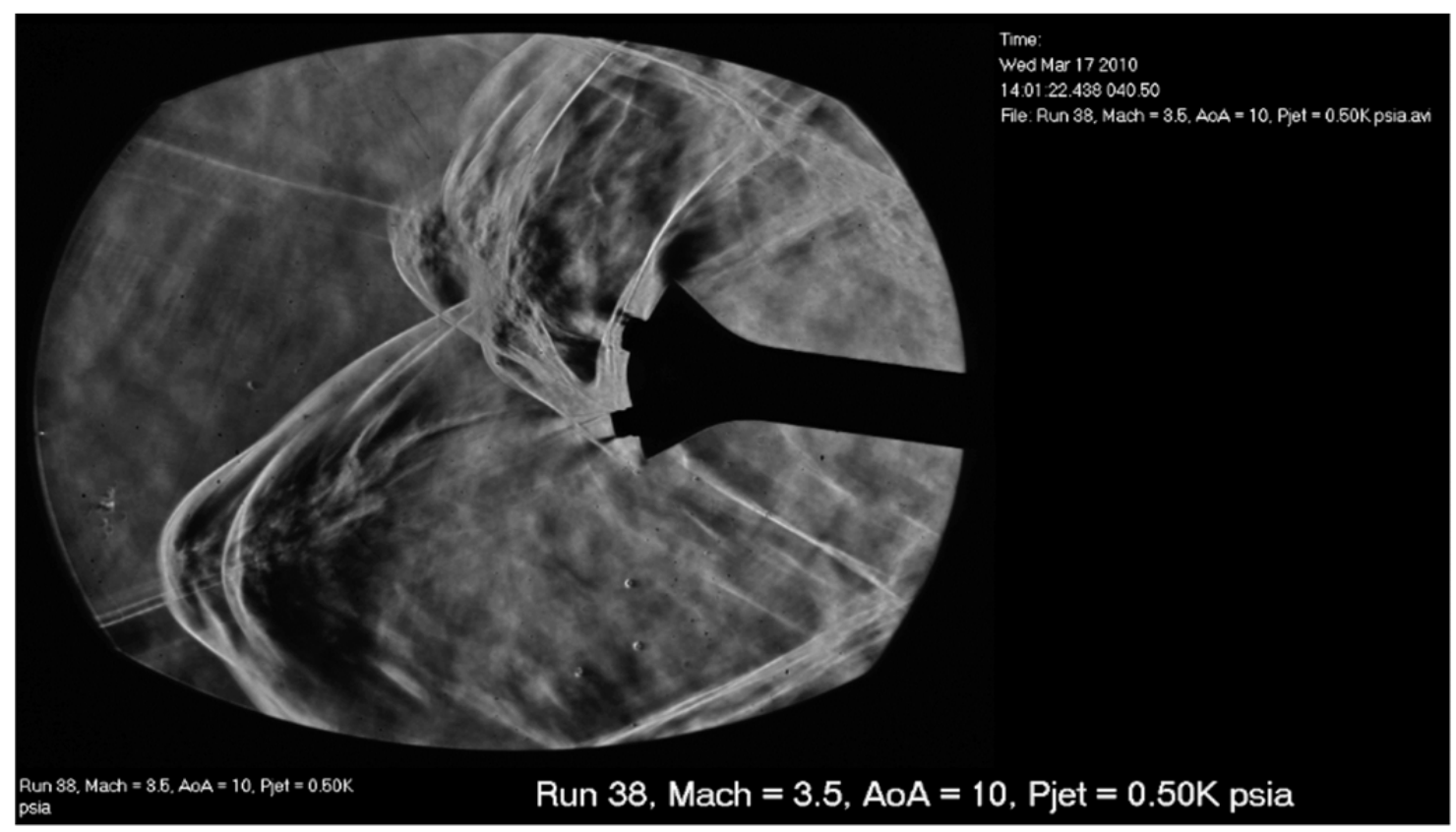

Figure A3-2.-Schlieren image from $1 \times 1$ SWT testing - three engine model, Mach $=3.5, \mathrm{Re} / \mathrm{ft}=1.86 \times 10^{6}$, and $P$, total $(p s i)=15.00, A o A=10$ degrees, 500 psia engine chamber pressure. 


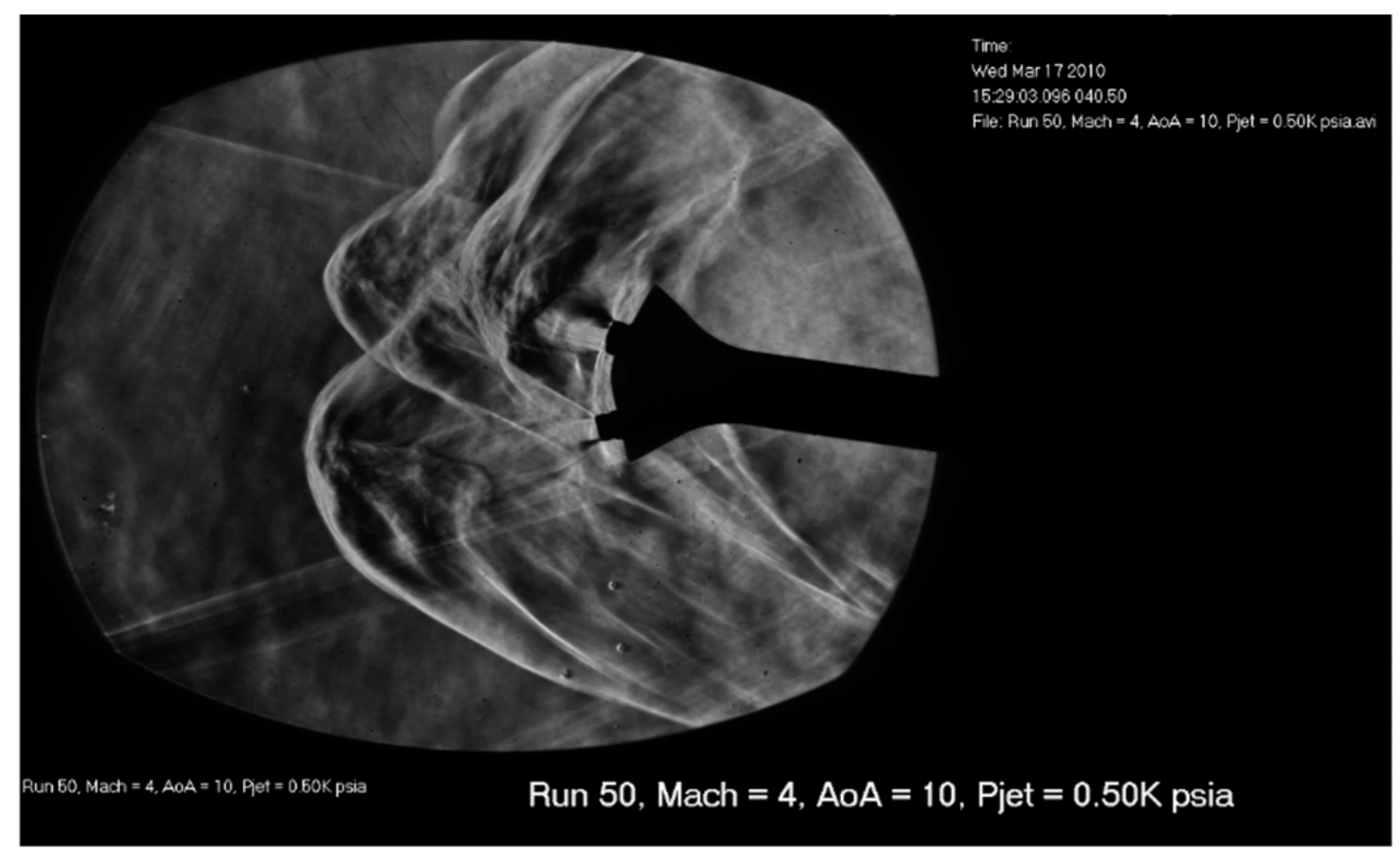

Figure A3-3.-Schlieren image from $1 \times 1 \mathrm{SWT}$ testing - three engine model, Mach $=4.0, \mathrm{Re} / \mathrm{ft}=2.56 \times 10^{6}$, and $P$, total $(\mathrm{psi})=26.01, \mathrm{AoA}=10$ degrees, 500 psia engine chamber pressure .

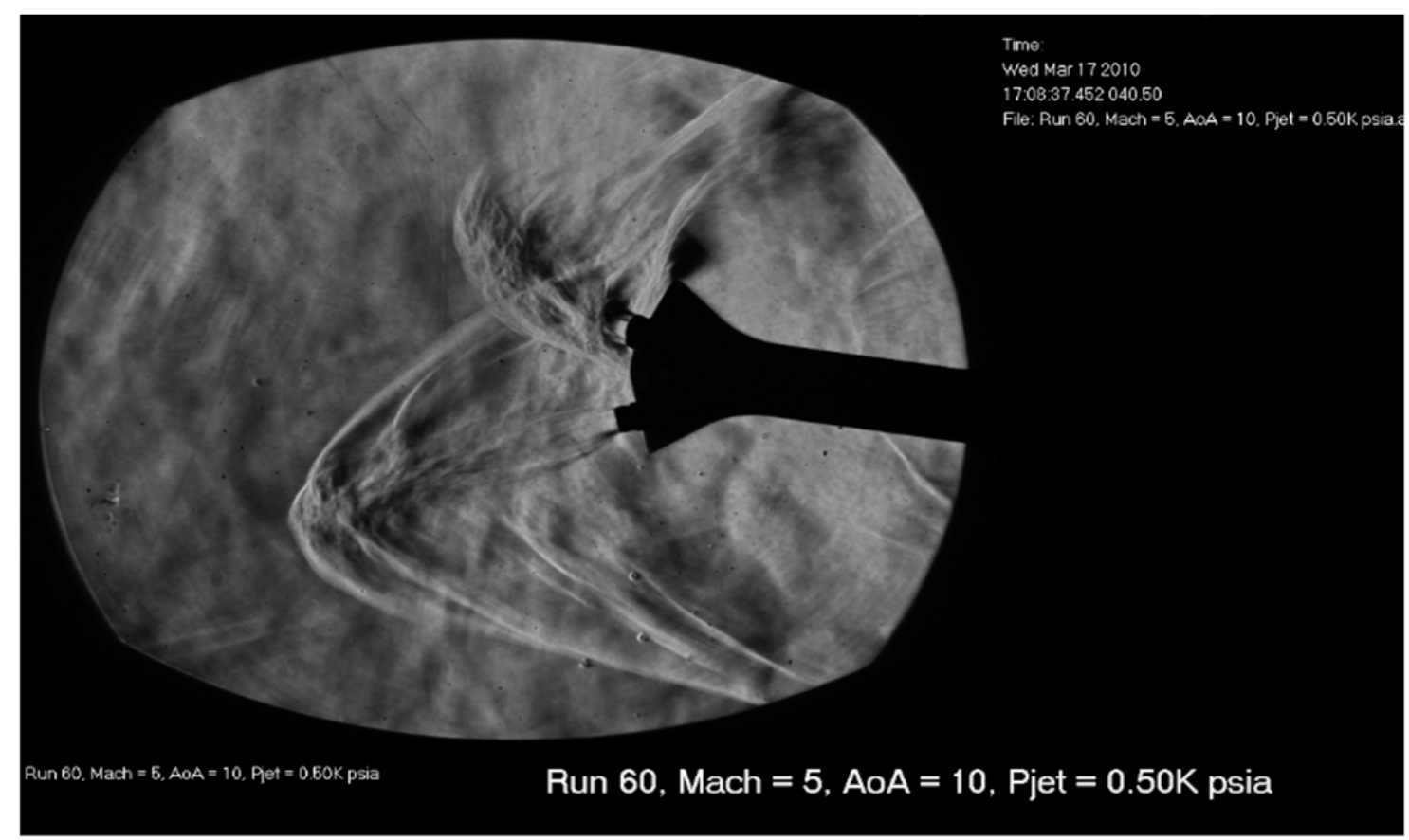

Figure A3-4.-Schlieren image from $1 \times 1$ SWT testing - three engine model, Mach $=5.0, \mathrm{Re} / \mathrm{ft}=5.42 \times 10^{6}$, and $\mathrm{P}$, total $(\mathrm{psi})=90.40, \mathrm{AoA}=10$ degrees, 500 psia engine chamber pressure. 


\section{Appendix B—SRP Run Data, $1 \times 1$ SWT}

TABEL II.-NASA EDL SRP $1 \times 1$ SWT TEST RESULTS SUMMARY NASA EDL SRP 1x1 SWT test results summary, 03-17-2010

\begin{tabular}{|c|c|c|c|c|c|c|c|c|c|c|c|c|}
\hline & RDG & SCAN & TOTAL_SCNAVG & & DATE & TIME & P,total (psia) & P, static (psia) & Mach Number & Reynolds/foot & Pjet (pia) & AOA (degrees) \\
\hline * & 6 & 1 & $1 \quad 1$ & 0 & 17-Mar-10 & $10: 05: 08$ & \begin{tabular}{|l|}
5.10347 \\
\end{tabular} & 0.3425 & 2.41215 & $1.10 E+06$ & 200 & 0 \\
\hline - & 7 & 1 & 1 & 0 & 17-Mar-10 & $10: 15: 37$ & 5.00908 & 0.335 & 2.41438 & $1.08 E+06$ & 200 & 10 \\
\hline * & 8 & 1 & 1 & 0 & 17-Mar-10 & $10: 23: 10$ & 5.05017 & 0.335 & 2.41961 & $1.08 E+06$ & 300 & 10 \\
\hline - & 9 & 1 & 1 & 0 & 17-Mar-10 & $10: 34: 14$ & 4.98458 & 0.3305 & 2.4199 & $1.07 E+06$ & 300 & 0 \\
\hline * & 10 & 1 & 1 & 0 & 17-Mar-10 & $10: 40: 37$ & 5.02854 & 0.333 & 2.4207 & $1.08 E+06$ & 500 & 0 \\
\hline & 11 & 1 & 1 & 0 & 17-Mar-10 & $10: 47: 04$ & 4.98026 & 0.3285 & 2.42324 & $1.07 E+06$ & 500 & 10 \\
\hline & & & & & & & & & & & & \\
\hline * & 16 & 1 & 1 & 0 & 17-Mar-10 & $11: 28: 13$ & 8.5857 & 0.2705 & 2.90301 & $1.44 E+06$ & 200 & 10 \\
\hline * & 17 & 1 & 1 & 0 & 17-Mar-10 & $11: 41: 31$ & 8.44954 & 0.2655 & 2.90478 & $1.41 E+06$ & 200 & 10 \\
\hline * & 18 & 1 & 1 & 0 & 17-Mar-10 & $11: 47: 55$ & 8.44737 & 0.265 & 2.90585 & $1.41 E+06$ & & \\
\hline * & 19 & 1 & 1 & 0 & 17-Mar-10 & $11: 51: 28$ & 8.47748 & 0.2655 & 2.90696 & $1.41 E+06$ & 200 & 0 \\
\hline * & 20 & 1 & 1 & 0 & 17-Mar-10 & $11: 58: 26$ & 8.66597 & 0.271 & 2.90794 & $1.45 E+06$ & 300 & 0 \\
\hline * & 21 & 1 & 1 & 0 & 17-Mar-10 & $12: 07: 46$ & 8.49397 & 0.266 & 2.907 & $1.42 E+06$ & 300 & 10 \\
\hline * & 22 & 1 & 1 & 0 & 17-Mar-10 & $12: 15: 42$ & 8.66238 & 0.2695 & 2.91134 & 1.44E+06 & 500 & 10 \\
\hline - & 23 & 1 & 1 & 0 & 17-Mar-10 & $12: 22: 04$ & 8.94823 & 0.285 & 2.89584 & $1.50 E+06$ & 500 & 0 \\
\hline & & & & & & & & & & & & \\
\hline - & 30 & 1 & 1 & 0 & 17-Mar-10 & 13:17:15 & 14.9783 & 0.207 & 3.46295 & $1.88 E+06$ & 200 & 0 \\
\hline * & 33 & 1 & 1 & 0 & 17-Mar-10 & $13: 36: 17$ & 15.0123 & 0.205 & 3.47135 & $1.87 E+06$ & 200 & 10 \\
\hline * & 34 & 1 & 1 & 0 & 17-Mar-10 & 13:37:19 & 15.0393 & 0.205 & 3.47261 & $1.87 E+06$ & 300 & 10 \\
\hline * & 35 & 1 & 1 & 0 & 17-Mar-10 & $13: 43: 25$ & 15.0024 & 0.2025 & 3.4795 & $1.86 E+06$ & 300 & 0 \\
\hline * & 36 & 1 & 1 & 0 & 17-Mar-10 & $13: 49: 28$ & 15.0258 & 0.203 & 3.47887 & $1.87 E+06$ & 300 & 15 \\
\hline * & 37 & 1 & 1 & 0 & 17-Mar-10 & $13: 55: 21$ & 14.8584 & 0.201 & 3.47795 & $1.85 E+06$ & 500 & 15 \\
\hline * & 38 & 1 & 1 & 0 & 17-Mar-10 & $14: 01: 20$ & 15.0031 & 0.203 & 3.4778 & $1.86 \mathrm{E}+06$ & 500 & 10 \\
\hline * & 39 & 1 & 1 & 0 & 17-Mar-10 & $14: 07: 15$ & 15.0038 & 0.1985 & 3.49359 & $1.85 E+06$ & 500 & 0 \\
\hline & & & & & & & & & & & & \\
\hline - & 43 & 1 & 1 & 0 & 17-Mar-10 & $14: 46: 17$ & 25.8632 & 0.1825 & 3.94839 & $2.55 E+06$ & 200 & 0 \\
\hline * & 44 & 1 & 1 & 0 & 17-Mar-10 & $14: 52: 20$ & 26.8485 & 0.1915 & 3.94039 & $2.66 \mathrm{E}+06$ & 200 & 10 \\
\hline - & 45 & 1 & 1 & 0 & 17-Mar-10 & $15: 00: 02$ & 26.1978 & 0.1845 & 3.94985 & $2.58 E+06$ & 200 & 15 \\
\hline * & 46 & 1 & 1 & 0 & 17-Mar-10 & $15: 05: 52$ & 26.3128 & 0.1875 & 3.9411 & $2.61 E+06$ & 300 & 15 \\
\hline * & 47 & 1 & 1 & 0 & 17-Mar-10 & $15: 11: 27$ & 25.9392 & 0.185 & 3.94045 & $2.57 E+06$ & 300 & 10 \\
\hline * & 48 & 1 & 1 & 0 & 17-Mar-10 & $15: 17: 25$ & 26.1281 & 0.185 & 3.94585 & $2.58 E+06$ & 300 & 0 \\
\hline * & 49 & 1 & 1 & 0 & 17-Mar-10 & $15: 23: 23$ & 26.3289 & 0.1855 & 3.94954 & 2.60E+06 & 500 & 0 \\
\hline * & 50 & 1 & 1 & 0 & 17-Mar-10 & $15: 29: 02$ & 26.0068 & 0.182 & 3.95456 & $2.56 E+06$ & 500 & 10 \\
\hline * & 51 & 1 & 1 & 0 & 17-Mar-10 & $15: 34: 48$ & 26.7106 & 0.187 & 3.95427 & 2. $63 E+06$ & 500 & 15 \\
\hline & & & & & & & & & & & & \\
\hline * & 57 & 1 & 1 & 0 & 17-Mar-10 & $16: 48: 45$ & 86.9416 & 0.176 & 4.94131 & $5.54 E+06$ & 200 & 15 \\
\hline - & 58 & 1 & 1 & 0 & 17-Mar-10 & $16: 56: 23$ & 90.1885 & 0.1675 & 5.01495 & $5.58 E+06$ & 300 & 15 \\
\hline * & 59 & 1 & 1 & 0 & 17-Mar-10 & $17: 02: 19$ & 89.7116 & 0.161 & 5.04444 & $5.48 E+06$ & 500 & 15 \\
\hline - & 60 & 1 & 1 & 0 & 17-Mar-10 & $17: 08: 35$ & 90.403 & 0.1535 & 5.09235 & $5.42 E+06$ & 500 & 10 \\
\hline$=$ & 61 & 1 & 1 & 0 & 17-Mar-10 & $17: 15: 12$ & 90.3647 & 0.1455 & 5.13857 & $5.32 E+06$ & 300 & 10 \\
\hline - & 62 & 1 & 1 & 0 & 17-Mar-10 & $17: 21: 26$ & 90.4469 & 0.14 & 5.17308 & $5.25 E+06$ & 200 & 10 \\
\hline * & 63 & 1 & 1 & 0 & 17-Mar-10 & $17: 27: 29$ & 90.0932 & 0.1325 & 5.21807 & $5.14 E+06$ & 200 & 0 \\
\hline * & 64 & 1 & 1 & 0 & 17-Mar-10 & $17: 33: 12$ & 92.3942 & 0.13 & 5.25723 & $5.19 E+06$ & 300 & 0 \\
\hline * & 65 & 1 & 1 & 0 & 17-Mar-10 & $17: 39: 16$ & 89.3562 & 0.118 & 5.31368 & $4.91 E+06$ & 500 & 0 \\
\hline
\end{tabular}





\section{Appendix C-Model Drawing, Front (Windward) of the Aeroshell}

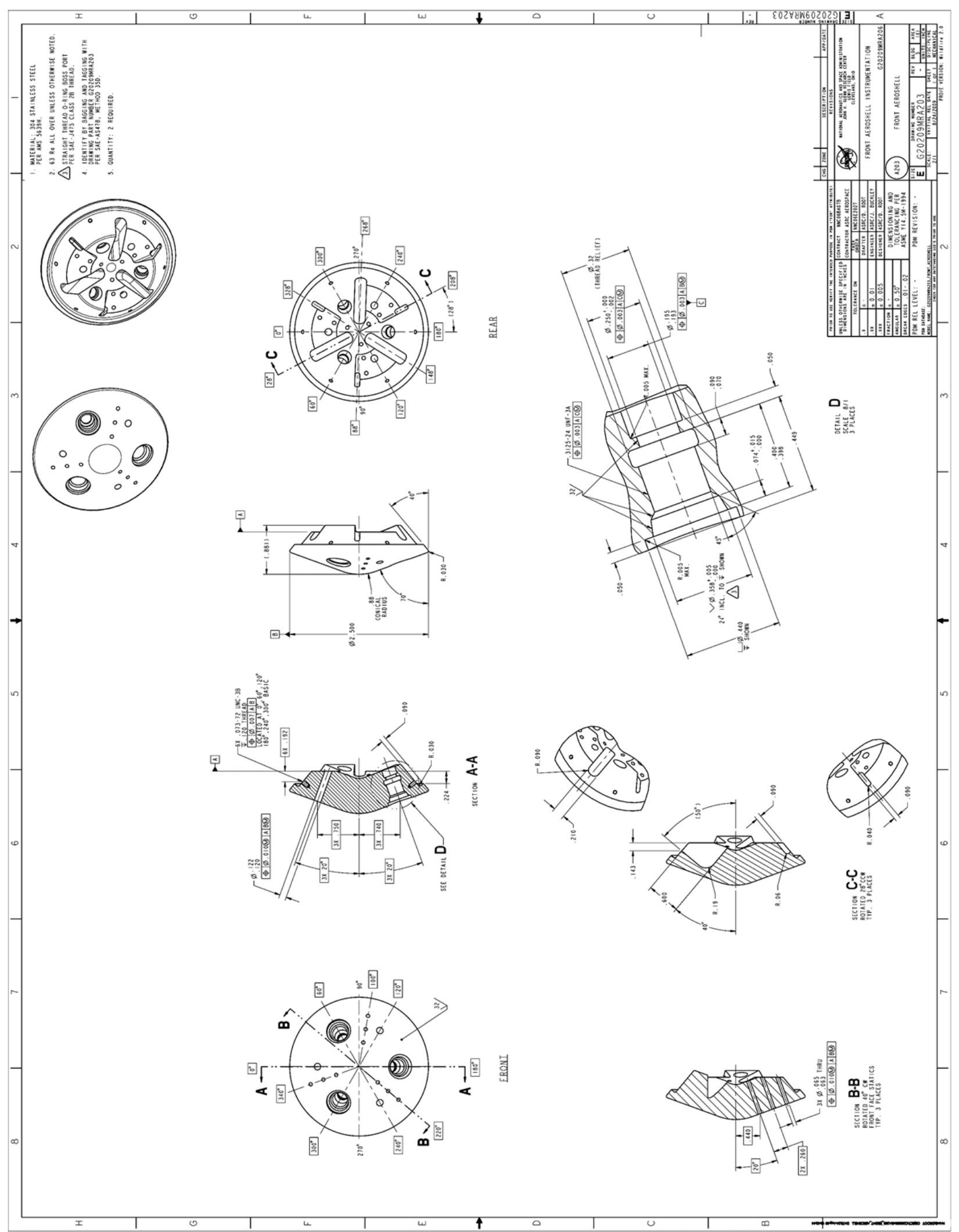




\begin{tabular}{|c|c|c|}
\hline \multicolumn{2}{|c|}{ REPORT DOCUMENTATION PAGE } & $\begin{array}{l}\text { Form Approved } \\
\text { OMB No. 0704-0188 }\end{array}$ \\
\hline \multicolumn{3}{|c|}{ 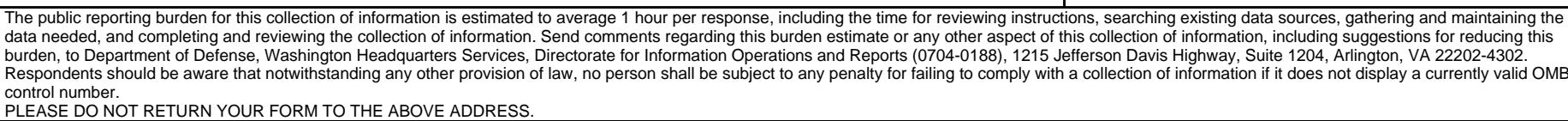 } \\
\hline $\begin{array}{l}\text { 1. REPORT DATE (DD-MM-YYYY) } \\
01-12-2012\end{array}$ & $\begin{array}{l}\text { 2. REPORT TYPE } \\
\text { Technical Memorandum }\end{array}$ & 3. DATES COVERED (From - To) \\
\hline \multirow{3}{*}{\multicolumn{2}{|c|}{$\begin{array}{l}\text { 4. TITLE AND SUBTITLE } \\
\text { Entry, Descent, and Landing With Propulsive Deceleration: Supersonic Retropropulsion } \\
\text { Wind Tunnel Testing }\end{array}$}} & 5a. CONTRACT NUMBER \\
\hline & & 5b. GRANT NUMBER \\
\hline & & 5c. PROGRAM ELEMENT NUMBER \\
\hline \multirow{3}{*}{\multicolumn{2}{|c|}{$\begin{array}{l}\text { 6. AUTHOR(S) } \\
\text { Palaszewski, Bryan }\end{array}$}} & 5d. PROJECT NUMBER \\
\hline & & 5e. TASK NUMBER \\
\hline & & $\begin{array}{l}\text { 5f. WORK UNIT NUMBER } \\
\text { WBS 017533.02.02.04 }\end{array}$ \\
\hline \multicolumn{2}{|c|}{$\begin{array}{l}\text { 7. PERFORMING ORGANIZATION NAME(S) AND ADDRESS(ES) } \\
\text { National Aeronautics and Space Administration } \\
\text { John H. Glenn Research Center at Lewis Field } \\
\text { Cleveland, Ohio 44135-3191 }\end{array}$} & $\begin{array}{l}\text { 8. PERFORMING ORGANIZATION } \\
\text { REPORT NUMBER } \\
\text { E-18481 }\end{array}$ \\
\hline \multirow{2}{*}{\multicolumn{2}{|c|}{$\begin{array}{l}\text { 9. SPONSORING/MONITORING AGENCY NAME(S) AND ADDRESS(ES) } \\
\text { National Aeronautics and Space Administration } \\
\text { Washington, DC 20546-0001 }\end{array}$}} & $\begin{array}{l}\text { 10. SPONSORING/MONITOR'S } \\
\text { ACRONYM(S) } \\
\text { NASA }\end{array}$ \\
\hline & & $\begin{array}{l}\text { 11. SPONSORING/MONITORING } \\
\text { REPORT NUMBER } \\
\text { NASA/TM-2012-217746 }\end{array}$ \\
\hline \multicolumn{3}{|c|}{$\begin{array}{l}\text { 12. DISTRIBUTIONIAVAILABILITY STATEMENT } \\
\text { Unclassified-Unlimited } \\
\text { Subject Categories: 01, 20, 34, and } 91 \\
\text { Available electronically at http://www.sti.nasa.gov } \\
\text { This publication is available from the NASA Center for AeroSpace Information, 443-757-5802 }\end{array}$} \\
\hline
\end{tabular}

\section{SUPPLEMENTARY NOTES}

\section{ABSTRACT}

The future exploration of the Solar System will require innovations in transportation and the use of entry, descent, and landing (EDL) systems at many planetary landing sites. The cost of space missions has always been prohibitive, and using the natural planetary and planet's moons' atmosphere for entry, descent, and landing can reduce the cost, mass, and complexity of these missions. This paper will describe some of the EDL ideas for planetary entry and survey the overall technologies for EDL that may be attractive for future Solar System missions. Future EDL systems may include an inflatable decelerator for the initial atmospheric entry and an additional supersonic retro-propulsion (SRP) rocket system for the final soft landing. As part of those efforts, NASA began to conduct experiments to gather the experimental data to make informed decisions on the "best" EDL options. A model of a three engine retro-propulsion configuration with a 2.5 in. diameter sphere-cone aeroshell model was tested in the NASA Glenn 1- by 1-Foot Supersonic Wind Tunnel (SWT). The testing was conducted to identify potential blockage issues in the tunnel, and visualize the rocket flow and shock interactions during supersonic and hypersonic entry conditions. Earlier experimental testing of a $70^{\circ}$ Viking-like (sphere-cone) aeroshell was conducted as a baseline for testing of a supersonic retro-propulsion system. This baseline testing defined the flow field around the aeroshell and from this comparative baseline data, retro-propulsion options will be assessed. Images and analyses from the SWT testing with 300- and 500-psia rocket engine chamber pressures are presented here. The rocket engine flow was simulated with a non-combusting flow of air.

\section{SUBJECT TERMS}

Planetary entry; Propulsion; Rocket engines; Fluid mechanics; Retrorocket; in situ resource utilization

\begin{tabular}{|c|c|c|c|c|c|}
\hline \multicolumn{3}{|c|}{ 16. SECURITY CLASSIFICATION OF: } & \multirow{2}{*}{$\begin{array}{l}\text { 17. LIMITATION OF } \\
\text { ABSTRACT } \\
\text { UU }\end{array}$} & \multirow{2}{*}{$\begin{array}{l}\text { 18. NUMBER } \\
\text { OF } \\
\text { PAGES } \\
32\end{array}$} & \multirow{2}{*}{$\begin{array}{l}\text { 19a. NAME OF RESPONSIBLE PERSON } \\
\text { STI Help Desk (email:help@sti.nasa.gov) } \\
\text { 19b. TELEPHONE NUMBER (include area code) } \\
\text { 443-757-5802 }\end{array}$} \\
\hline $\begin{array}{l}\text { a. REPORT } \\
\text { U }\end{array}$ & $\begin{array}{l}\text { b. ABSTRACT } \\
U\end{array}$ & $\begin{array}{l}\text { c. THIS } \\
\text { PAGE } \\
\text { U }\end{array}$ & & & \\
\hline
\end{tabular}



